\title{
تقدير الاحتياجات النفسية والاجتماعية للمعاقين : دراسة استطلاعية علي عينات بالمملكة العربية السعودية
}

\author{
إعداد \\ د. سحر أحمد حسين سليم

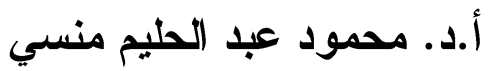 \\ أستاذ مساعد علم النفس سلف \\ أستاذ علم النفس - كلية التربية

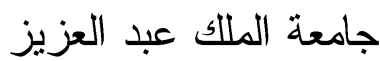 \\ جامعة الإسكندرية
}

$$
\text { مجلة|لاراسات التربوية والاساثية - كلية التربية - جامعة دمنهور }
$$


تقلير الاحتياجات النفسية والاجتماعية للمعاقين أ.د. محمود عبد الحليم منسي د. سحر أحمد حسين سليم 
تقدير الاحتياجات النفسية والاجتماعية للمعاقين : دراسة استطلاعية علي عينات بالمملكة العربية السعودية

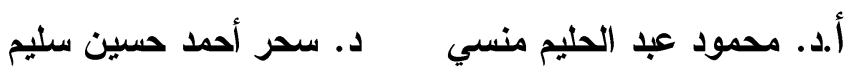

\section{الملخص}

هدف هذا البحث إلى تحديد الاحتياجات النفسـية و الاجتماعيــة للمعــاقين

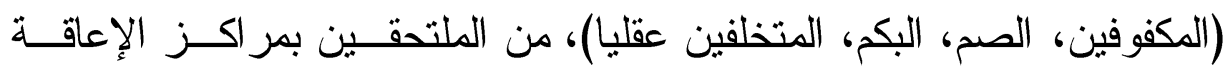

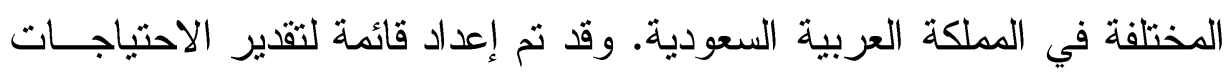

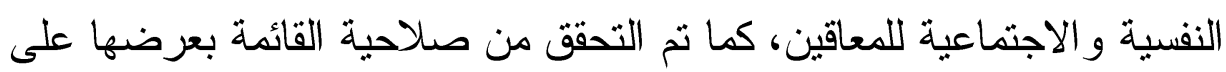

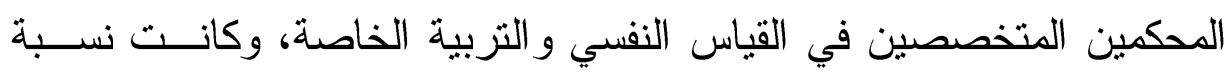

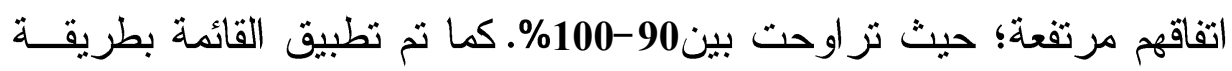
فردية على عينة مكونة من (300) معاق من ذوي الإعاقات المختلفة (المعاقين

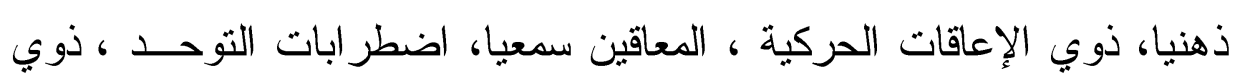

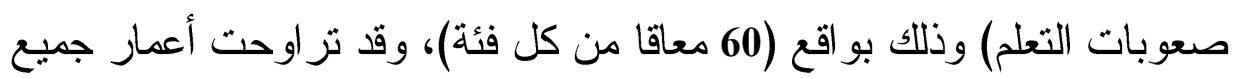
أفر اد العينة بين 12.9 سنة إلى 16.2 سنة.

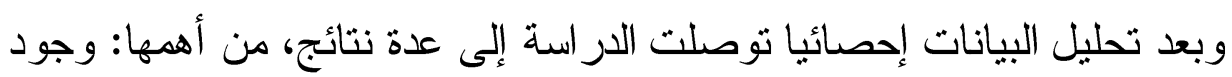

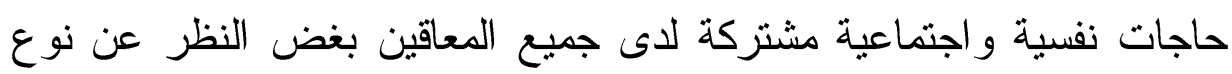

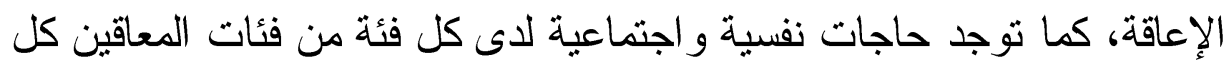
على حدة، وقد تم تقديم بعض التوصيات و المقترحات التي تساعد على إثباع الحاجات الخاصة بكل فئة من فئات المعاقين. 


\section{• مقدمة :}

أن بناء وتتمية القدر ات البشرية العربية هي إحدى قضايا الســاعة التـي

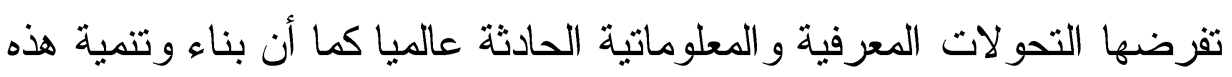
القدر ات يجب أن يشمل كافة فئات المجتمع ، و هنا تبرز الحاجة إلي تأهيل ذوي

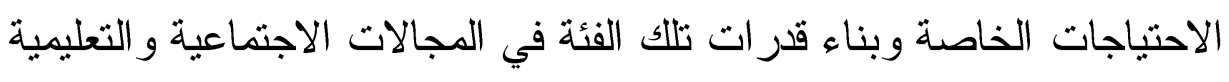
و الاقتصادية في مو اجهة الوضع الحالي للمعاقين الذي يوسم بالعجز و القصور

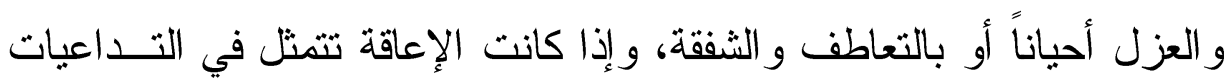

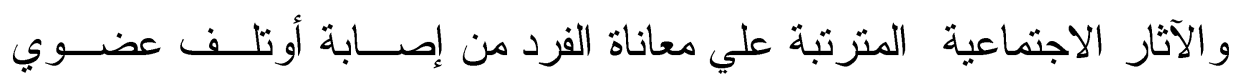

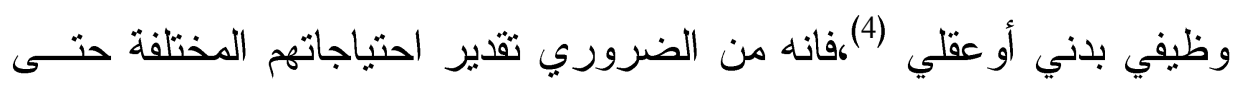

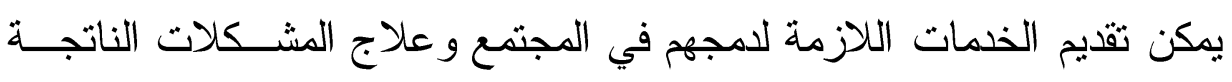

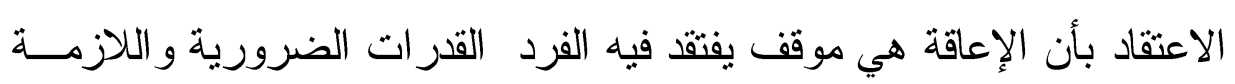
لإشباع حاجاته الأساسية وتطلعاته ومشاركته في فعاليات الحياة العامة أو إعتبار أن الإعاقة تعكس نقص الأحقية الضرورية للمشاركة المجتمعية .

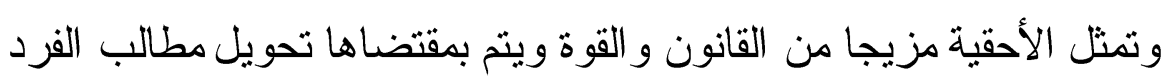
إلي أمر و اقع في ظل امتلاكه للقوة وتحت مظلة القانون وبمقتضي نظام أحقية

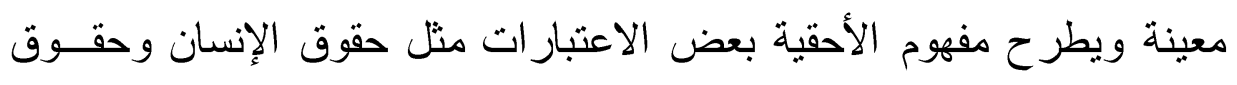

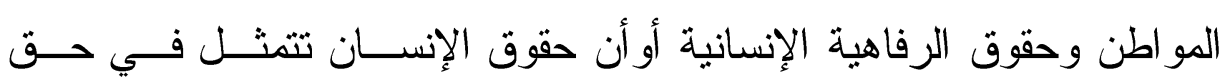

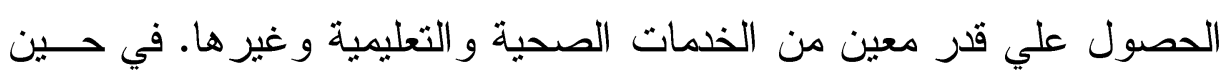
يرتبط مفهوم حقوق المو اطن بمفهوم الطاعة و أداء الضر ائب وخلافة. كما يهتم مفهوم الرفاهية الإنسانية بكيفية تطوير حياة الفرد و استغلال قدر اته كاملة دون

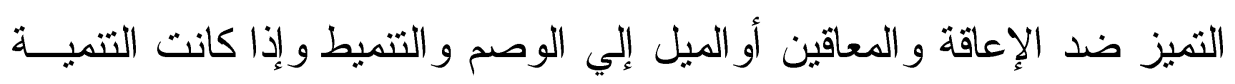

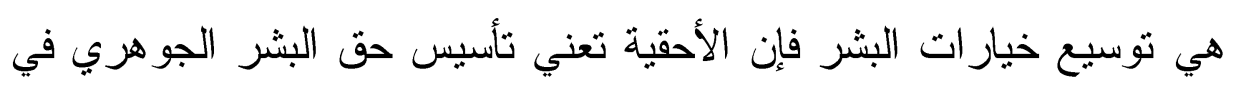

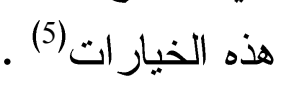


ومفهوم ذوي الإعاقات هومفهوم يتسع ليشمل عدة فئات اجتماعية غير ذوي الحاجات الجسمية الخاصة مثل الإعاقة (الذهنية - الســمعية - البصــرية - لإهـية

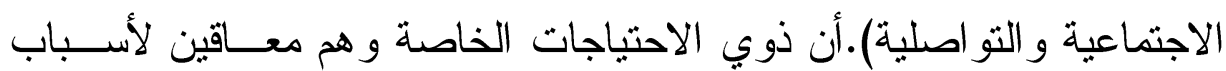
بعضها ور اثي وبعضها بيئي (حادث سيارة - إصابة عمل - سو ع ثقديم الخدمة قبل الحمل و أثناء الو لادة - كذلك يضم إليهم المعاق ثقافيا وسياسيا، ويعكس إسل ذلك مدي اتساع فئات الإعاقة . وتعرف الإعاقة Handicap بكونها فقدان أوتهميش أومحدودية المشاركة في فعاليات و أنشطة وخبرات الحياة الاجتماعية عند مستوي مماتل للعاديين وذلك

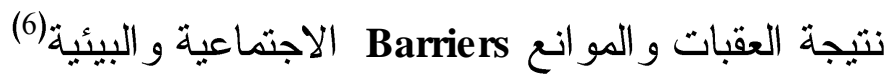
•أسئية البحث: ينطلق البحث من السؤال التالي : ما أهم احتياجات المعاقين للمعارف والاتجاهات و القيم و المهارات التي تمكنه من الاندماج في فعاليات الحياة الاجتماعية؟ ويتفرع من هذا السؤ ال الأسئلة التالية : 1. ما أهم الاحتياجات النفية و الاجتماعية للمعاقين ذهنيا؟

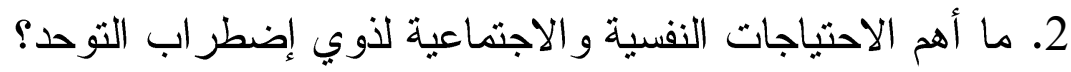
3. ما أهم الاحتياجات النفسية و الاجتماعية للمعاقين سمعيا؟ الاحنياج 4. ما أهم الاحتياجات النفسية والاجتماعية للمعاقين حركيا؟

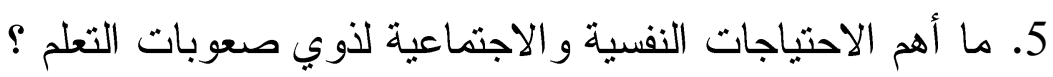




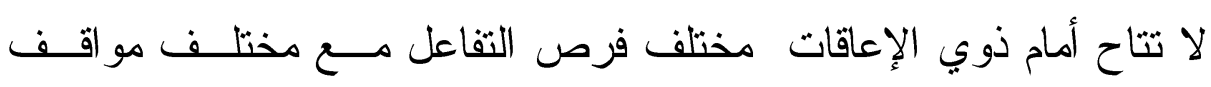
وخبر ات الحياة الاجتماعية، ويعيشون في مستوي جودة حياه أقل كثير امقارنة

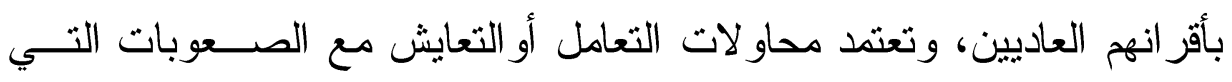

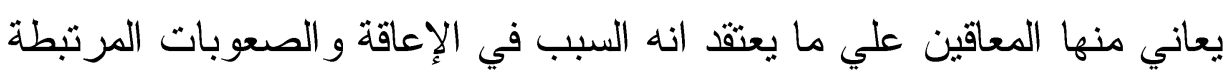
بها ويوجد طريقتين مختلفتين لتفسير ما يعتقد انه السبب في الإعاقة وتداعياتها النفسية وقد أمكن بلورة هاتين الطريقتين فيما بطلق علية نموذجا لتفسير الإعاقة :

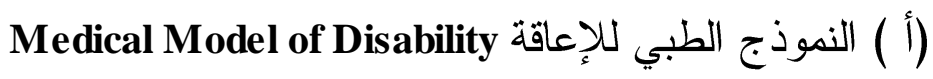

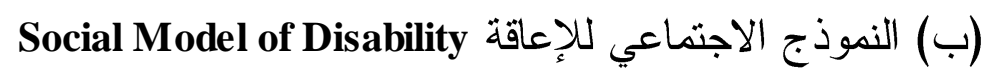
يهتم النموذج الطبي علي الملامح و الخصائص الأساسية للفرد، في حين يتبني

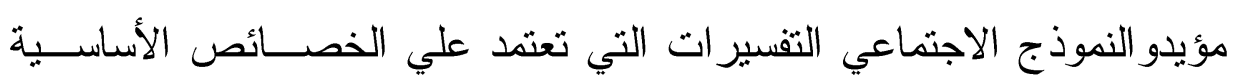

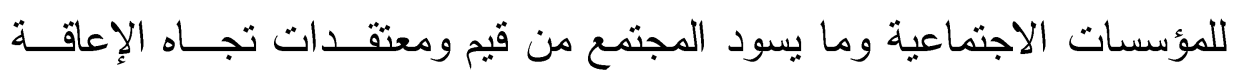
و المعاقين وفيما يلي عرض موجز لكلا النموذجين : 1 - النموذج الطبي للإعاقة :

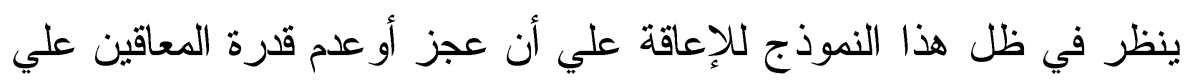

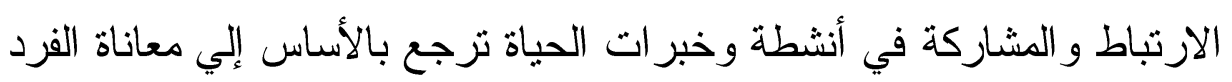
من إصابة Impairment تتلف أوتحدث تحمير العضوما من جسده يترتب علية

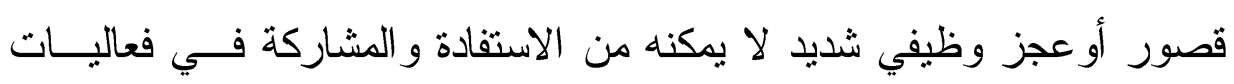

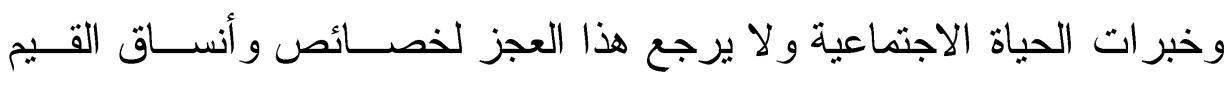

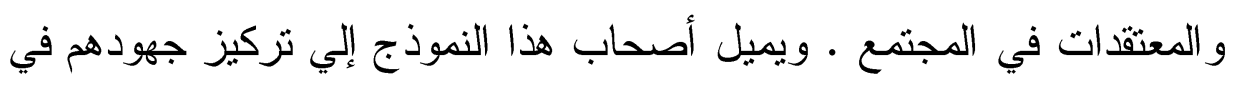

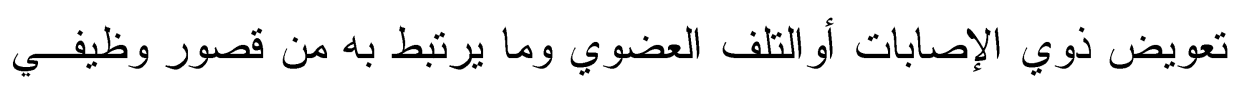

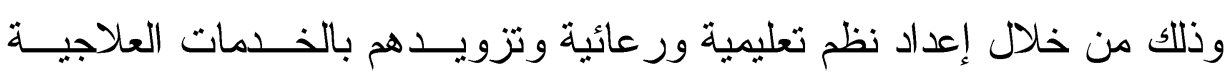

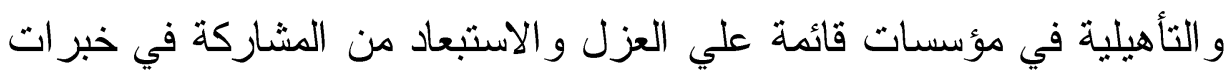
الحياة الاجتماعية العادية. 
ويؤثر النموذج الطبي للإعاقة أيضا علي الطريقة التي يري بها في ذو اتهم

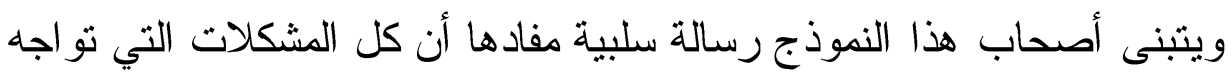
المعاقين تتشأ نتيجة اضطر ابات نمائية وخلل عضوي، و وعادة ما يميل المعاقين

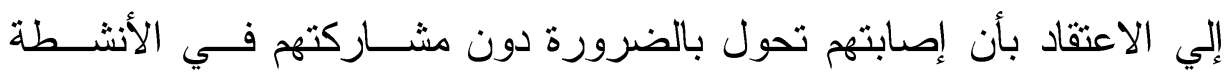
الاجتماعية، ويؤدي دخول هذه المعتقدات في البنية الفكرية لذوي الإعاقة إلـي لـي

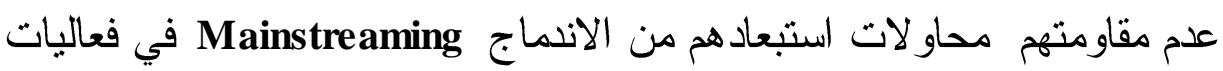

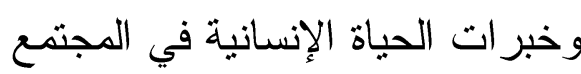

$$
\begin{aligned}
& \text { 2- النموذج الاجتماعي للإعاقة : }
\end{aligned}
$$

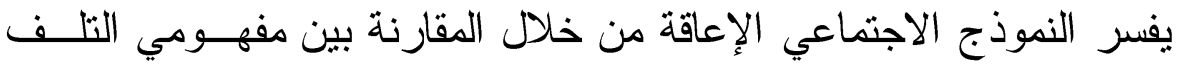
Impairment و العجز Disability وقد بدأت صياغة النموذج الاجتماعي مسن الإعن قبل بعض الباحثين بعد إظهار بعض المعاقين استيائهم من النمــوذج الطبــي

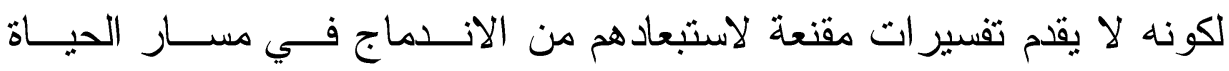

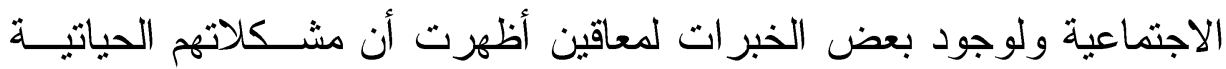

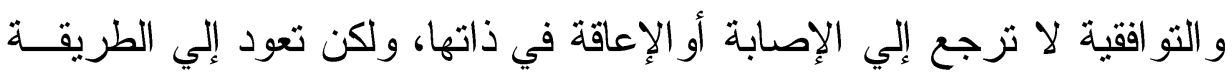

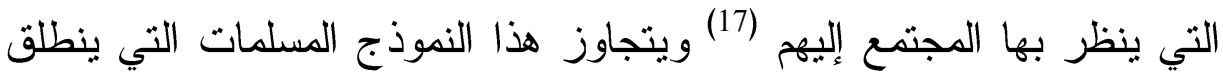
منها النموذج الطبي و التي تتمثل في عدم التقرقة بين الإصابة و التلف، و العجز

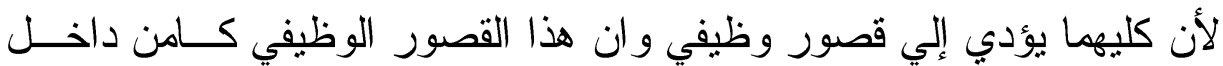

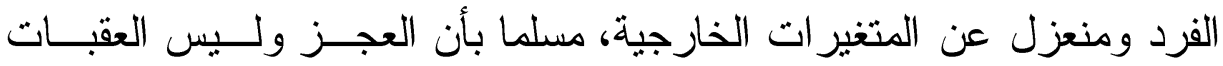

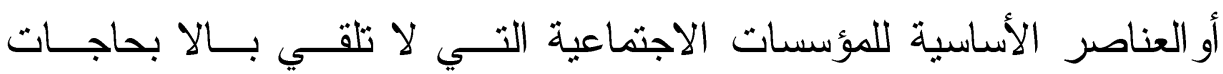

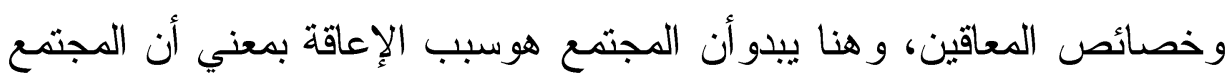

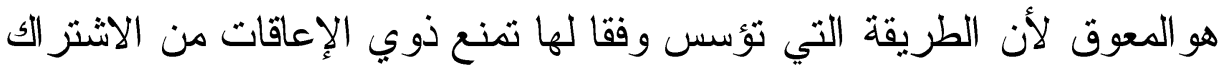

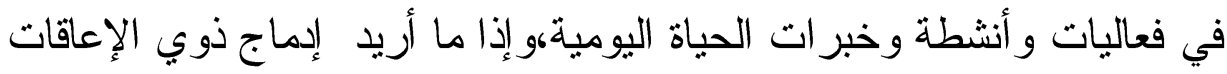
في الحياة الاجتماعية فمن الضروري أن يعاد تتظيم المجتمع من حيث بنائـــهـ 
ووظائفه، وللقضاء علي العقبات التي تحول دون هذا الدمج. ومن هذه العقبات أو الحو اجز :

- التحيز ضد الإعاقة و المعاقين و الميل إلي الوصح و التنميط . - عدم مرونة الإجر اءات و الممارسات المؤسساتية - تعذر الحصول علي المعلومات الصحيحة - تعذر وجود المؤسسات المناسبة للمعاقين - تعذر وجود وسائل المو اصلات و النقل المناسبة (18) ويشير تحليل " هنت " (Hunt) إلي أنه يعتقد أن المعاقين يو اجهون اضطهادا

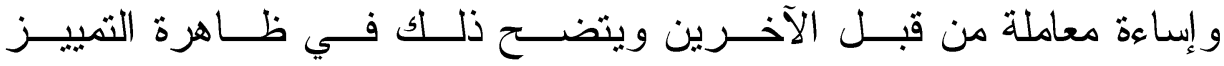
Discrimination هنت " إلي التأكيد علي وجود علاقة مباشرة بين الاتجاهات الاجتماعية والثقافية

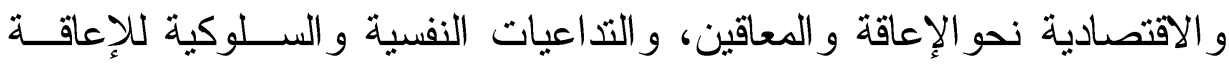

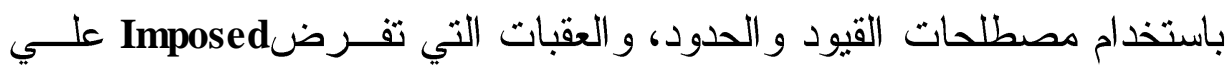
المعاقين من قبل المؤسسة، وقد استخلم المعاقون في بداية السبعينيات من القرن

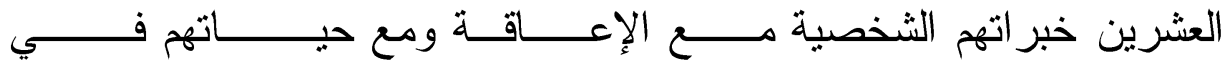

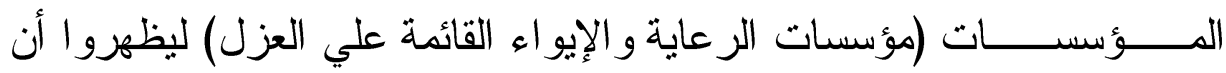

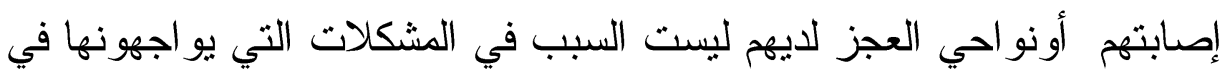
حياتهم أوفي التذاعيات النفسية و السلوكية المصاحبة للإعاقة، وأن السبب فئي لئي

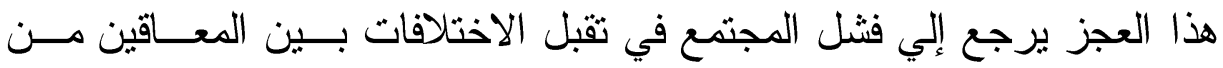

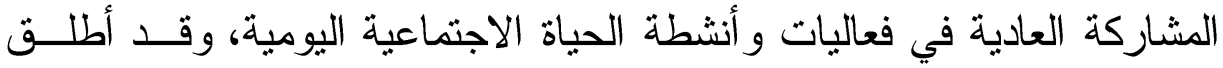
علي هذه الطريقة في التفكير بالنموذج الاجتماعي للإعاقة، إذ يفسر فيه العجز

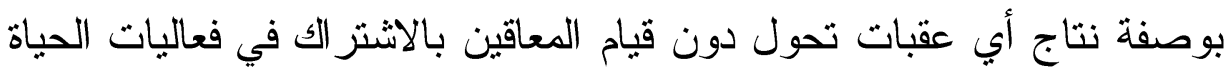

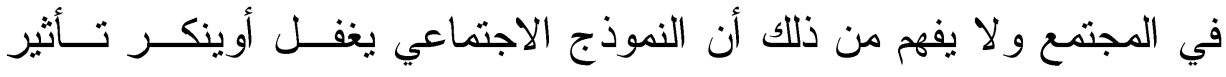

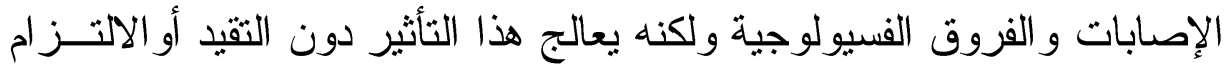


بالأحكام ذات الطبع التقويمي لذا فمن المتصور أن استخدام النموذج الاجتماعي

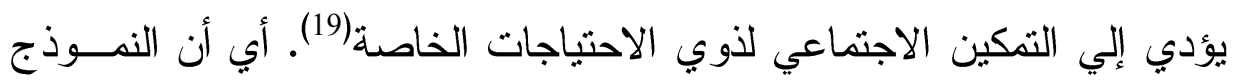

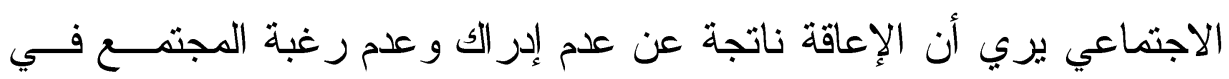

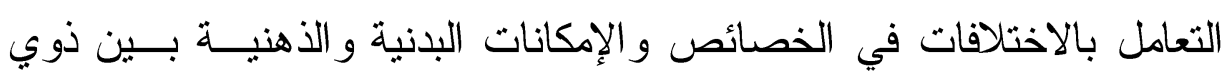
الإعاقات و أقر انهم العاديين

\section{متطلبات ذوي الاحتباجات الخاصة : الإنة}

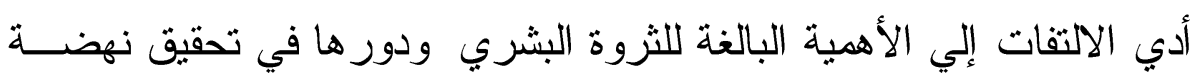

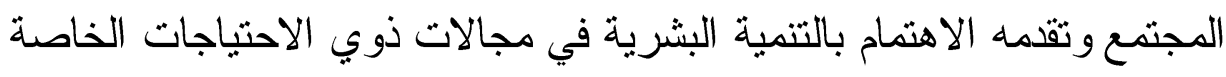

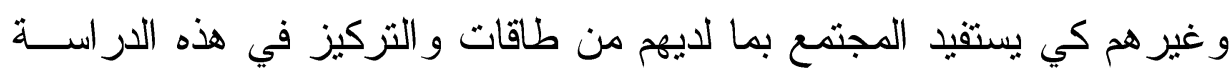

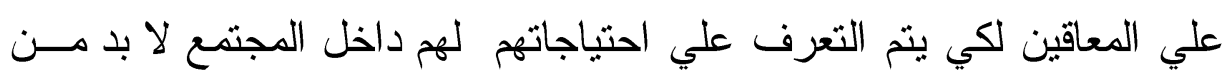

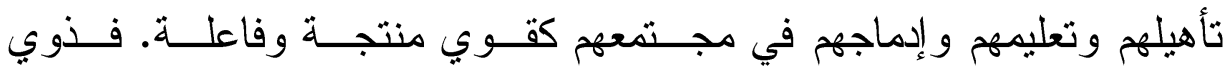

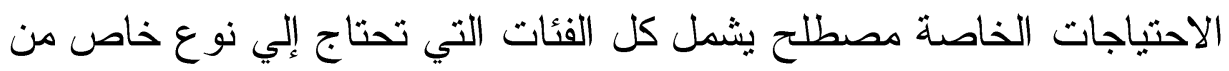

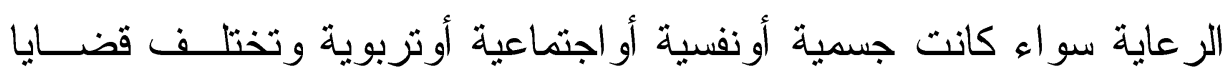

ومشكلات وطرق رعاية كل فئة من هذه الفئات لاختلاف احتياجاتهم (37). إن من متطلبات تمكين ذوي الاحتياجات الخاصة هى توفير كافة أثــــال

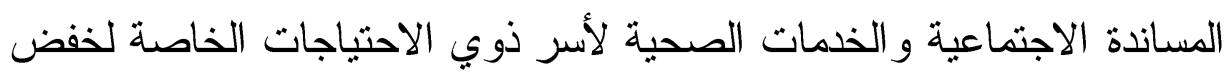
مستويات الضغوط النفسية الو اقعة علي هذه الأسر (38). وتتير "Fahmeeda Wahab" إلي أن ذوي الاحتياجات الخاصة يتعرضون الإن في كافة المجتمعات إلي مختلف صور التمييز السلبي وخاصة الاستبعاد مسن

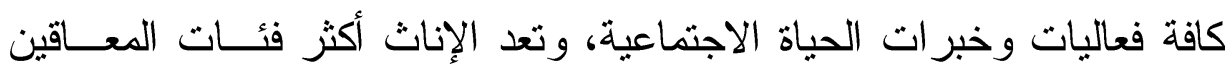

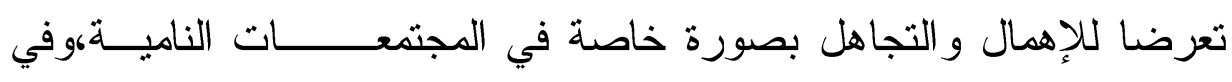

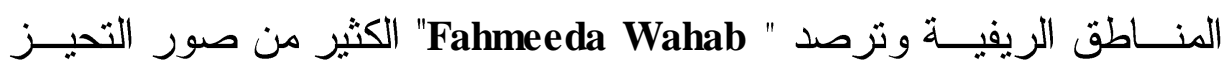

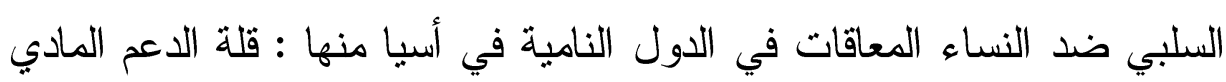

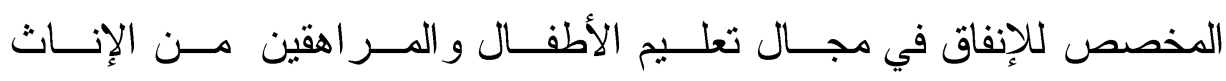


المعاقات،إضافة إلي عدم تأهيلهم بالصورة الكافية لامجهم في المجتمع وبنــاء

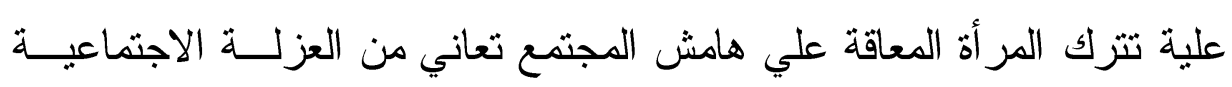

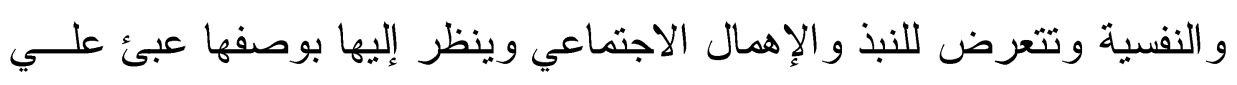

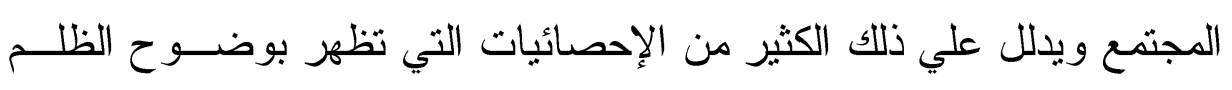

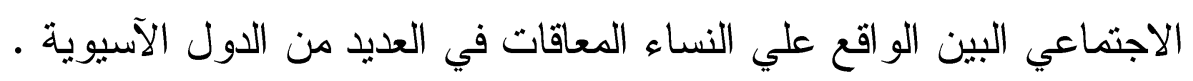
ويرجع هذا إلي القصور في النتريعات المتعلقة بتعليم ورعاية المعـاقين و هي تعد و احدة من أهم الأسباب التي تزتبط بهذا الظلم الاجتماعي وتؤكد علي

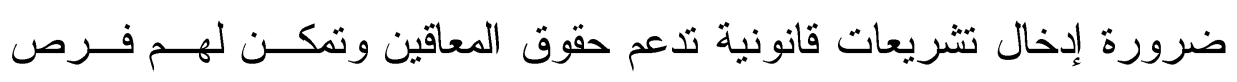

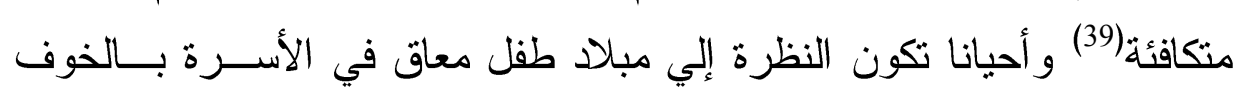

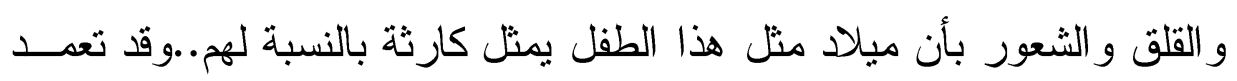

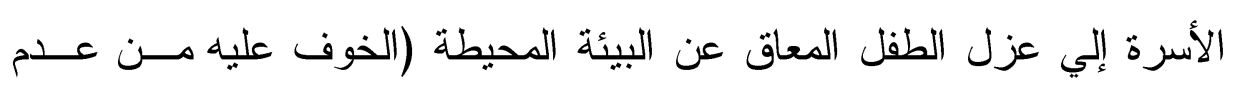

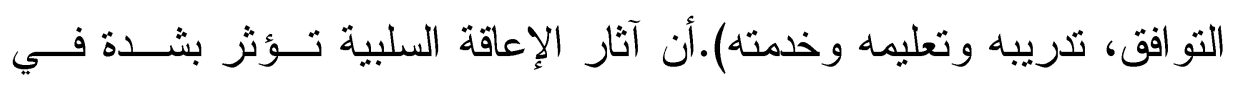

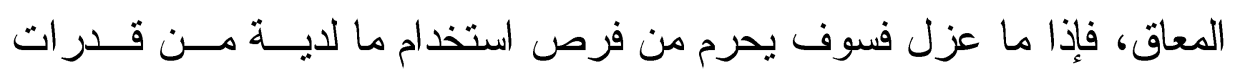

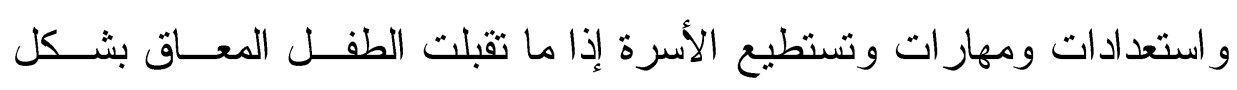

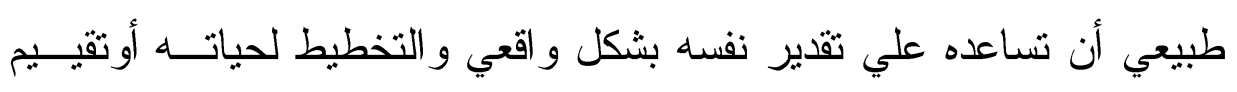
قدر اته و استعداداته بصورة صحيحة دون زيادة أونقصان (40). و هنا تطر ح قضية العلاقات المتذاخلة بين مستوي التحصيل الدر اسي للأطفال

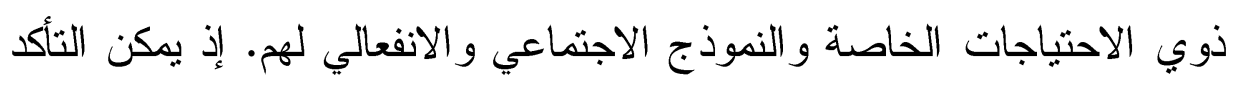
بصفة عامة على أن ذوي الاحتياجات الخاصة - يتعلمون بصورة أفضل حال

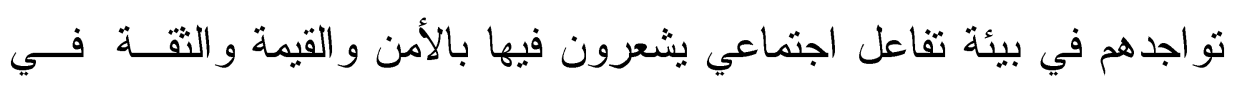

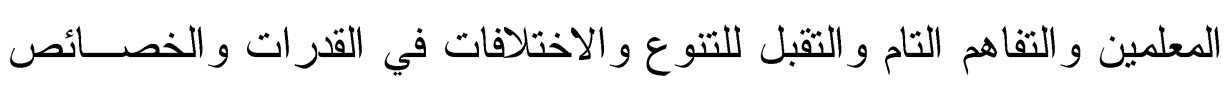

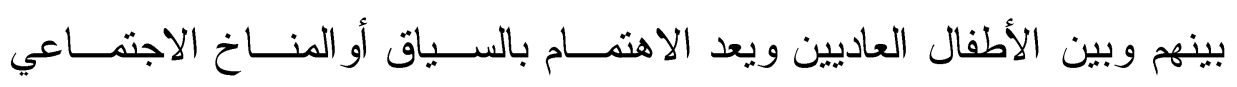
و الانفعالي للتعلم من القضايا ذات التأثير الفعال (42) 


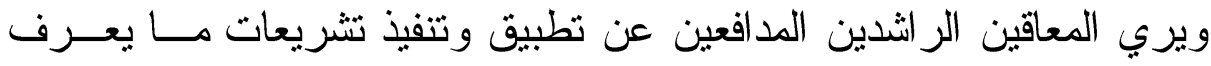

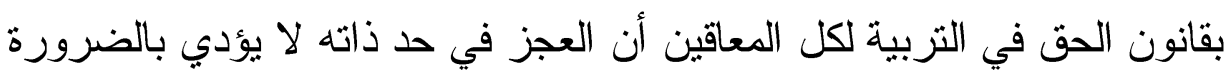

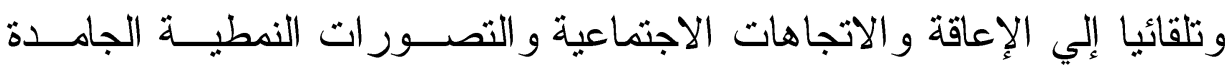

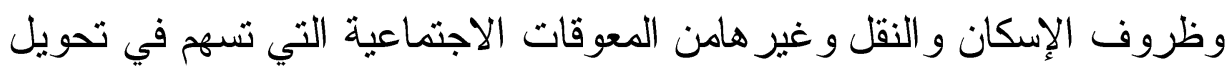

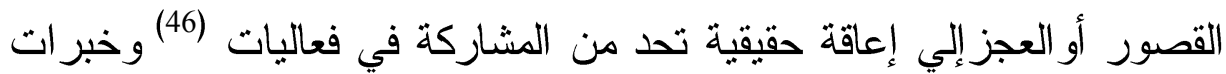
الحياة الاجتماعية.

إن قضية تمكين ذوي الاحتياجات الخاصة ودمجهم في المجتمع اندماجا كليا

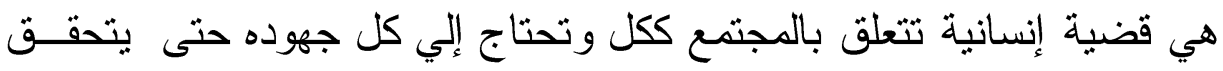

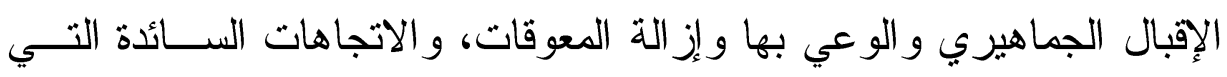

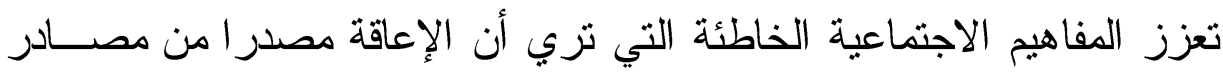

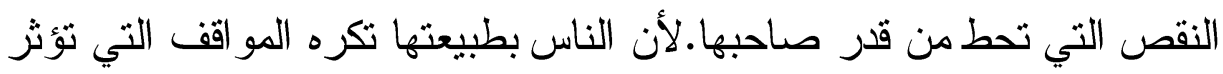

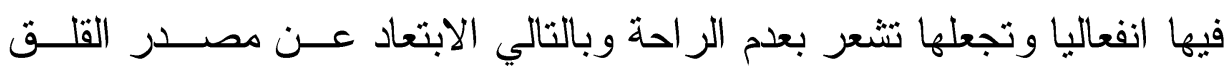

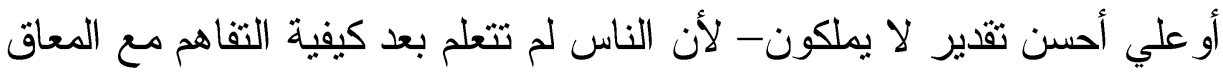

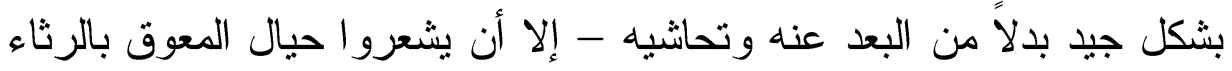

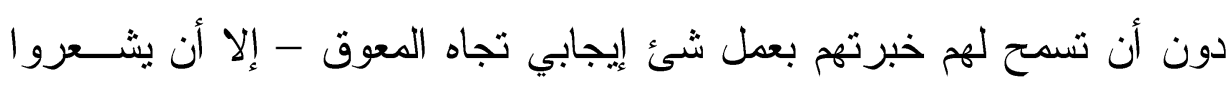

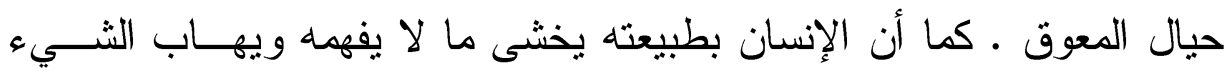

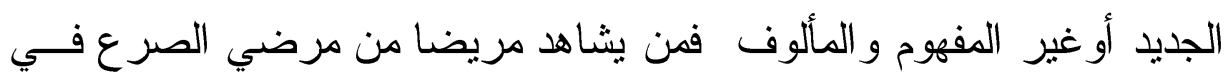

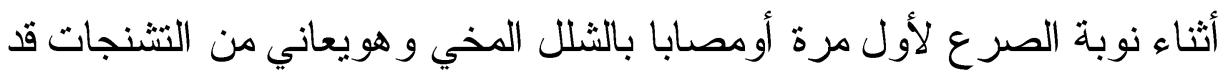

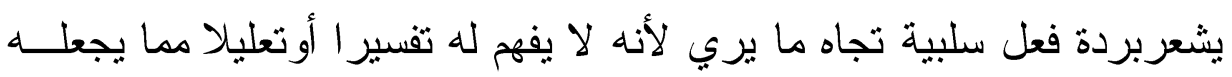

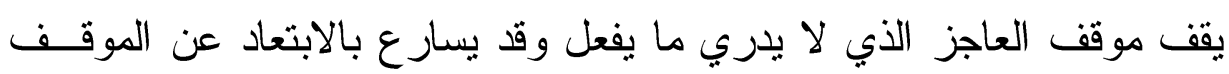
(47) ويذهب William Roth إلى أن إعاقة مثل الثلل الأماغي لا يعــد مأســاة

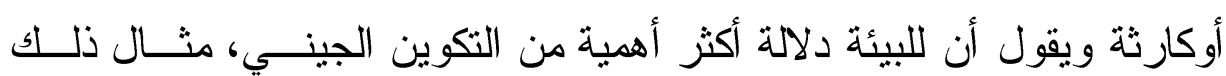
الشخص الفقير الذي يعيش في منزل غير جيد التهوية ومحاط بمصادر التلوث

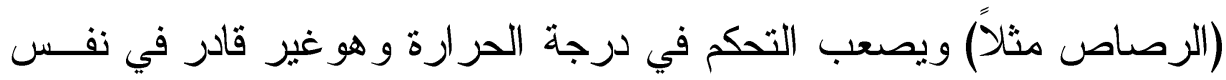




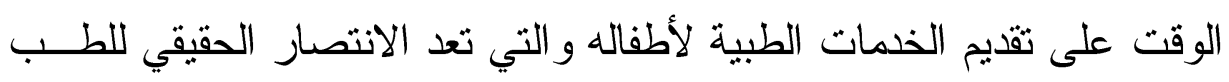

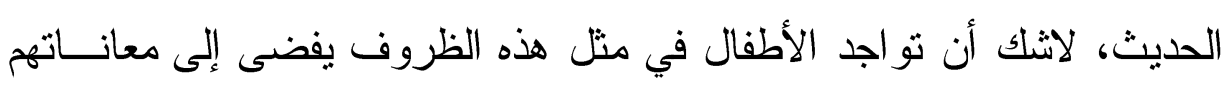

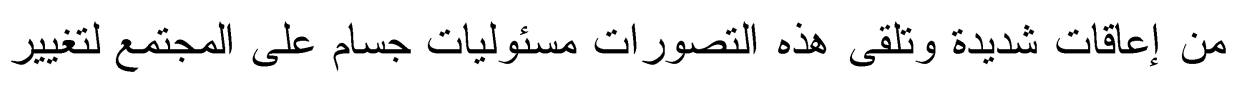

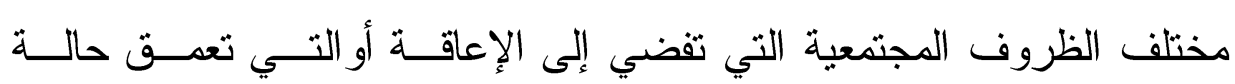

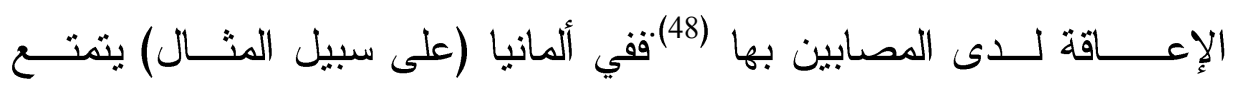

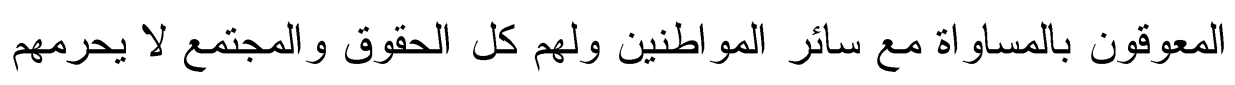

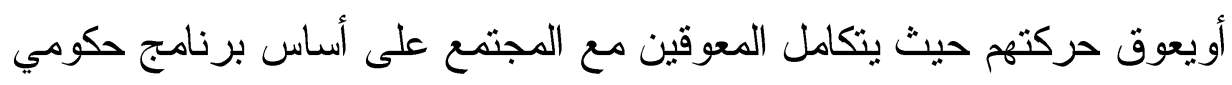

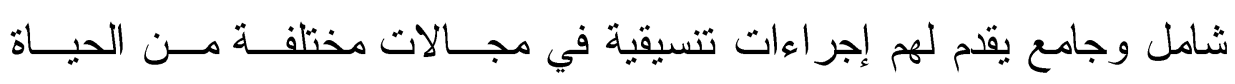

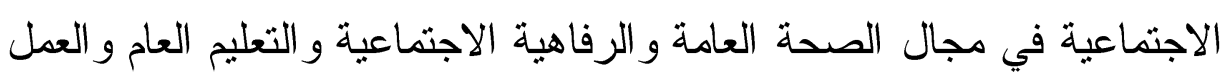

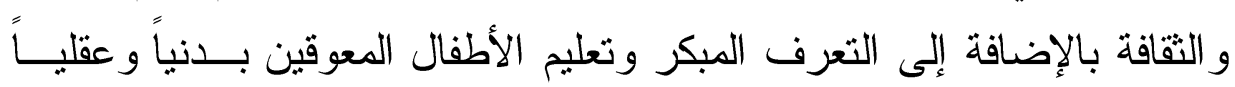

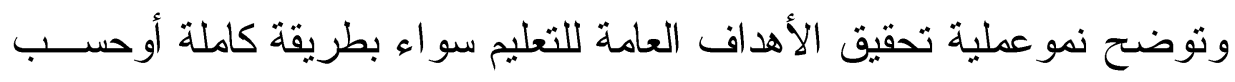

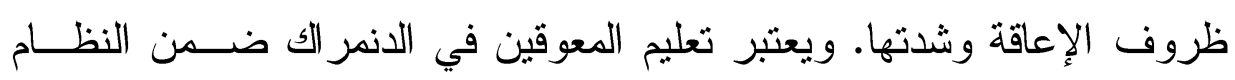

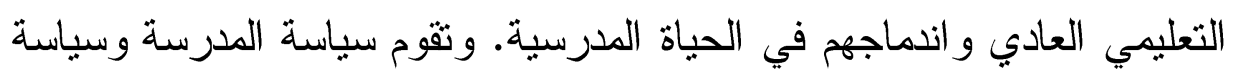
المجتمع على خلق صلات وثيقة بين الناس على حد سواء لا فرق بين العاديين منهم و المعوقين • ونجد في إيطاليا القانون ينص على التعليم الإلز امي للأطفال

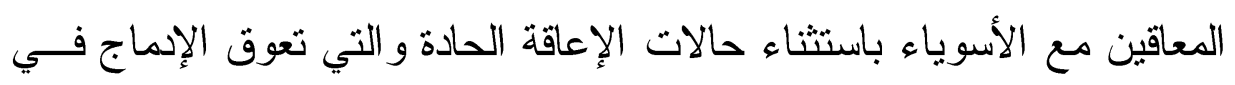

$$
\text { الفصول العادية(49). }
$$

وقد توصلت نتائج البحوث و الدر اسات السابقة مــن أن البـــر امج الموجهــة

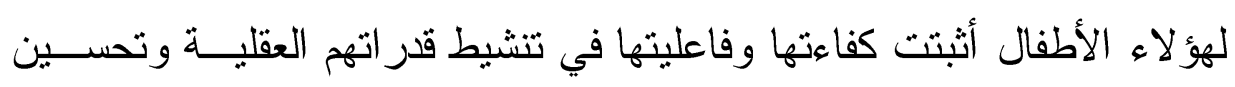

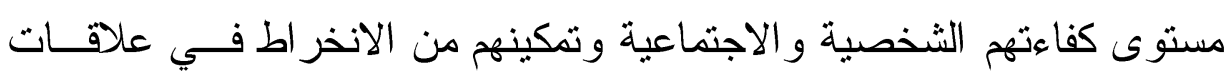

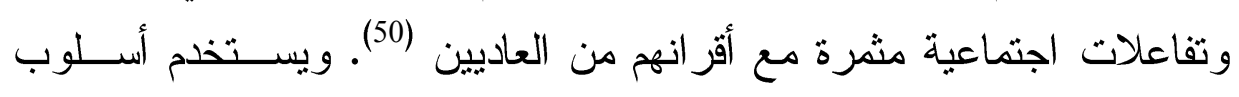

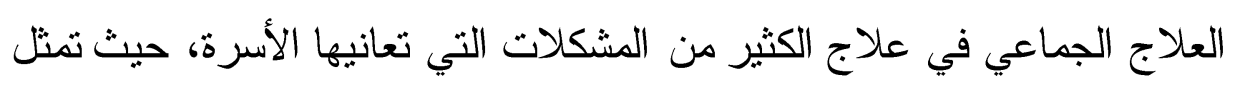

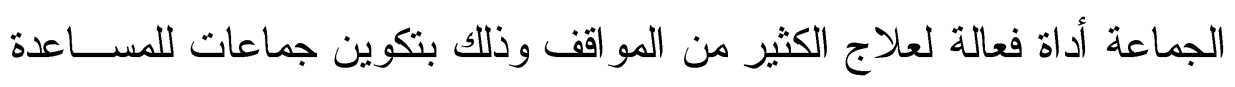
الذاتية حيث أن هذه الجماعات تتكون من أسر لديها اهتمامات مشتركة ويأنون 


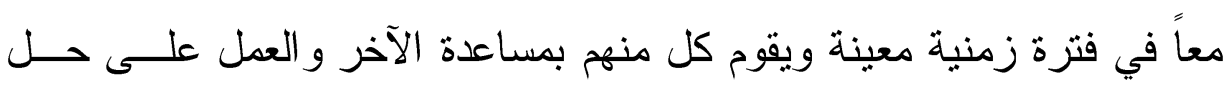

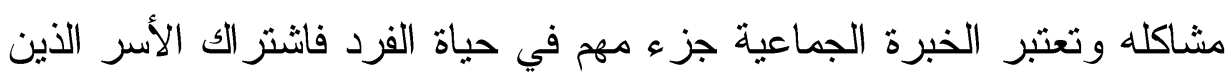

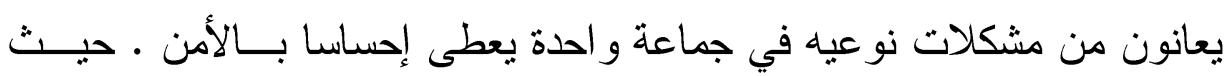

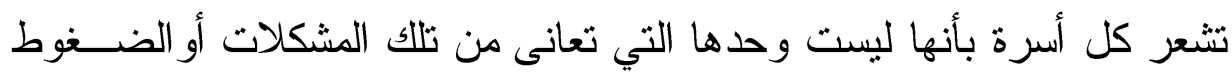

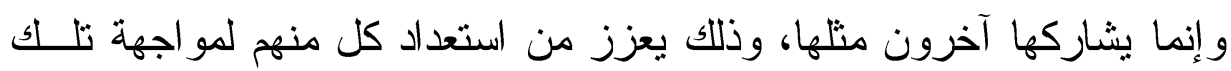
(51) المشكلات 3- الاميج الاجتماعي_:

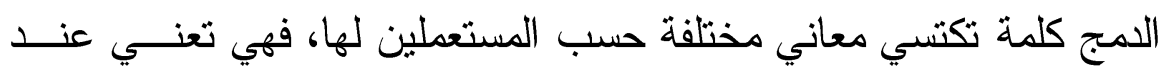

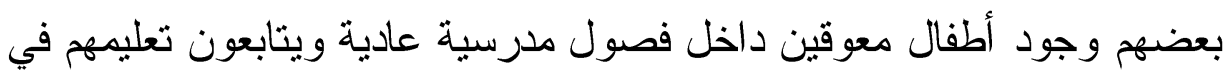

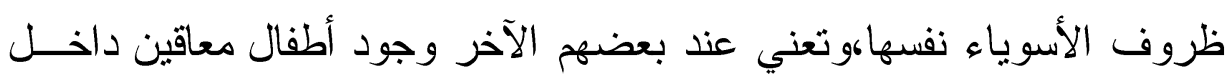

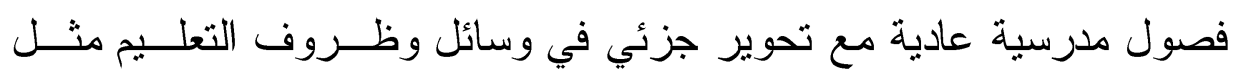

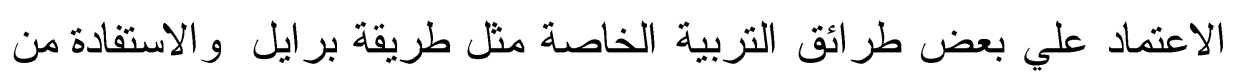

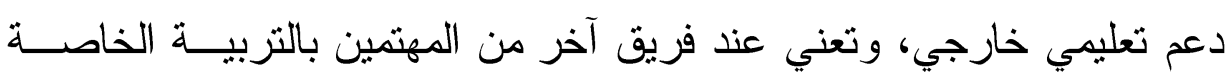

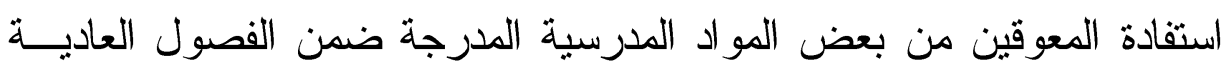

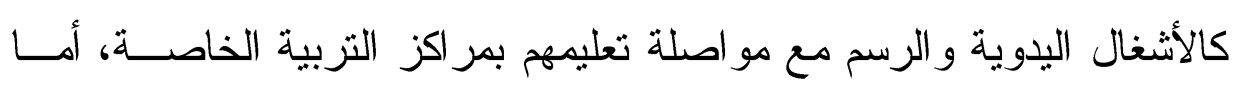

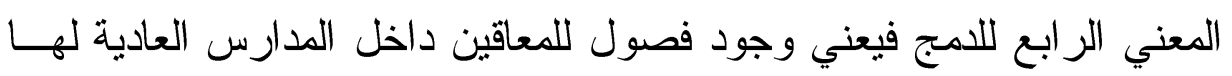

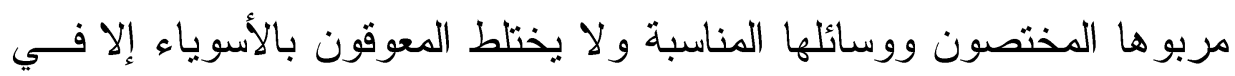
فناء المدرسة أوفي بعض المناسبات(20)

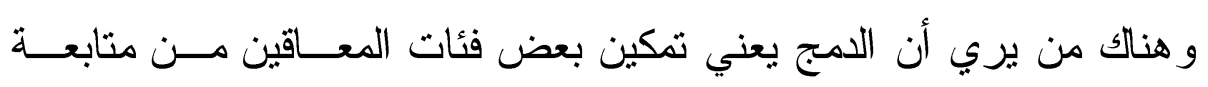

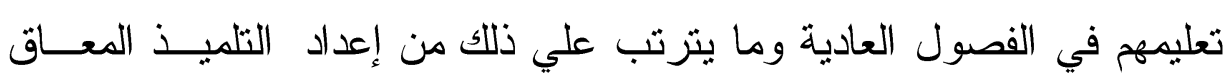

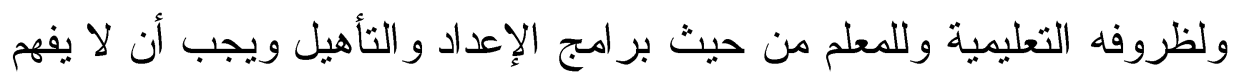

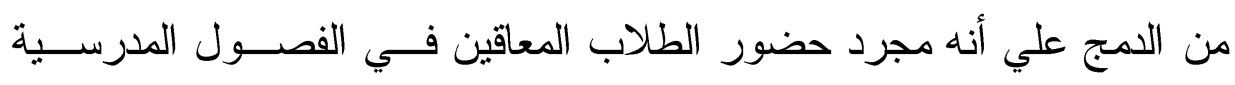

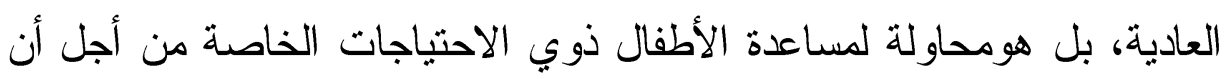

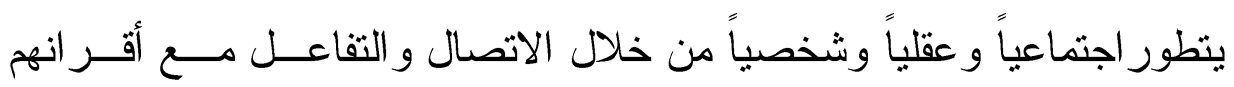


العاديين، و هذا يتطلب إحداث تغيير في المدرسة و المناهج وطر ائـق التعلــيم

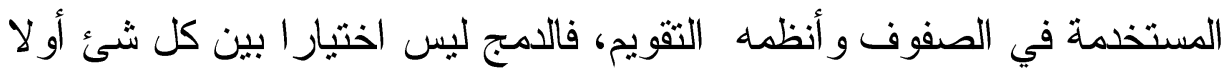

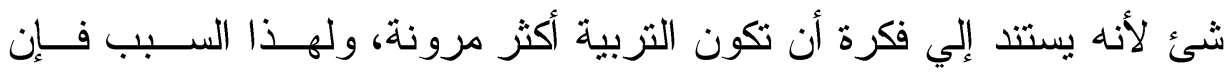
التلاميذ الذين يعانون من أي صعوبات سوف يكونون قريبين مـنـ أقــر انهم

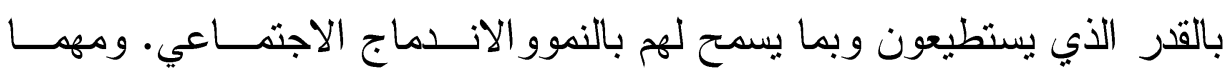

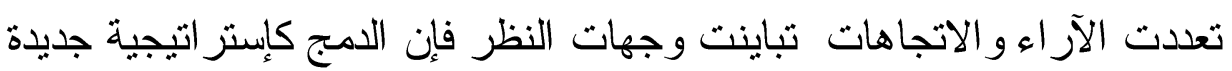
في التزبية الخاصة ينطلق من الأتي:

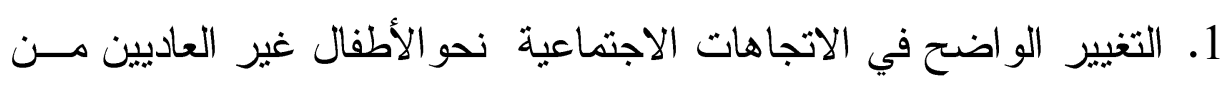
السلبية إلي الإيجابية.

2. توفير الفرصة الطبيعية للأطفال غير العاديين للنمو الاجتماعي و التزبوي مع الإبة

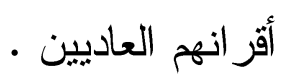
3. إز الة الوصمة المرتبطة ببعض فئات التزبية الخاصة، ويقصد بذلك الآثار

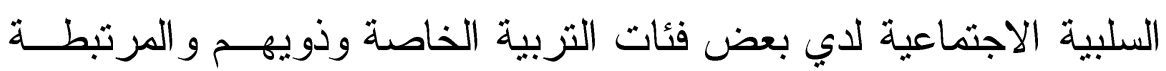
بمصطلح مثل الإعاقة (21) وقد ترتب علي ما سبث ظهور أفكار جديدة دفعت بحركة تربية ورعايــة

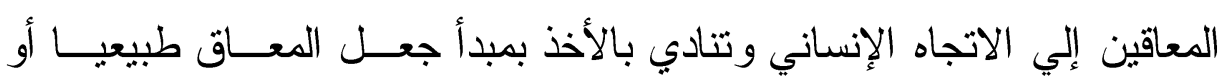

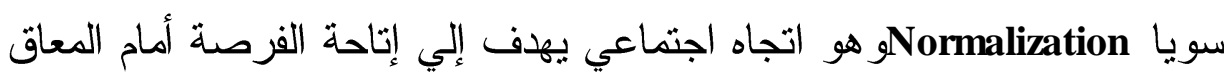

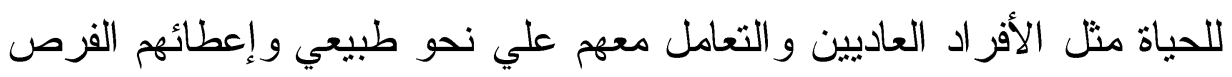

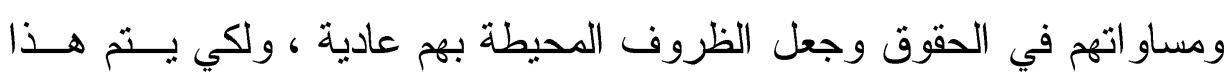

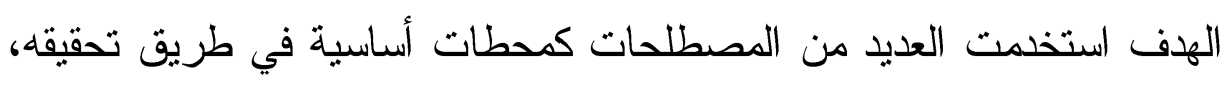

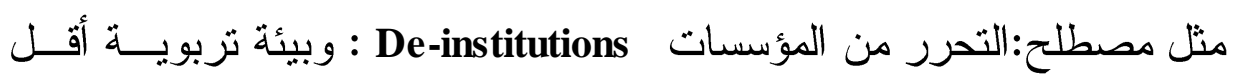

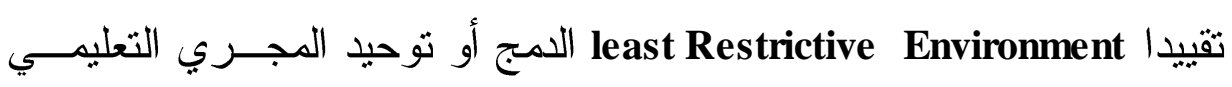

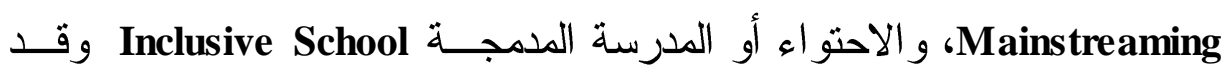
استخدم مصطلح التحرير من المؤسسات ليشير إلي تلك العملية التي تتضــمن 
إبعاد المعوقين عن المؤسسات الخاصة الداخلية ووضعهم في بيئات مفتوحسـة

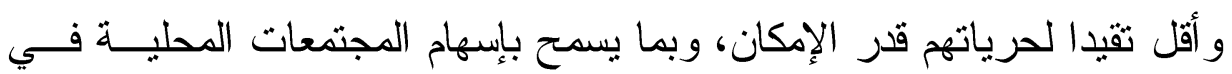
رعاية المعوقين بصورة تساعد علي تعويدهم الحياة بين أقرانهم العـاديين(22)

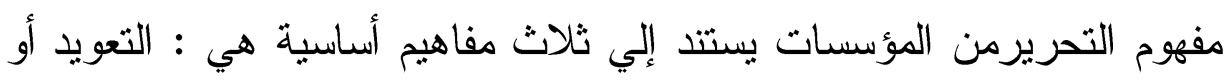
النطبيع - بيئة أقل تقييدا- الأسلوب النمائي. وقد ظهر مصطلح الدمج الذي يقضي بأن تتاح للمعوقين نفس أســاليب

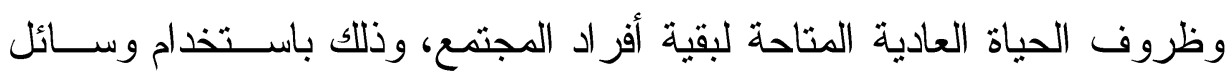

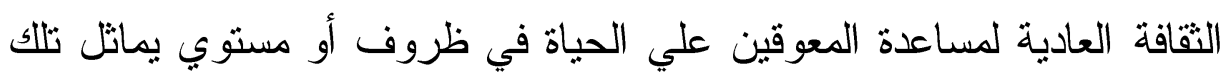

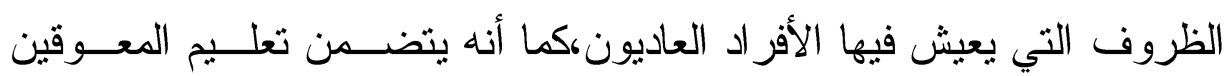

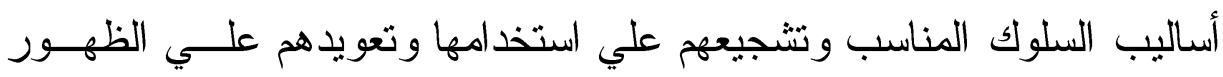
بالمظهر اللائق، وتعريضهم لخبرات متعددة تقربهم من أساليب الحياة العاديــة

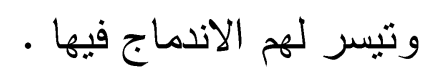
وقد استخدم البعض مصطلح التكامل ليشير إلي ضرورة تعليم المعـوقين

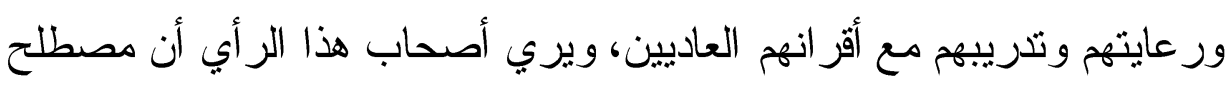

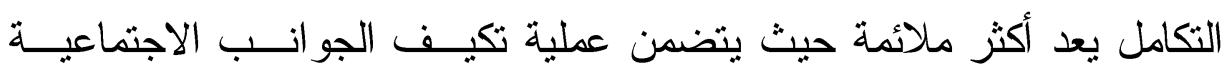

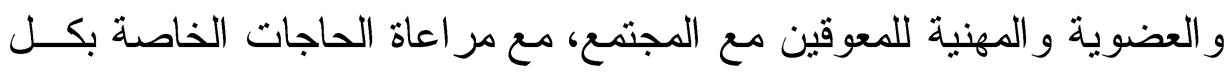

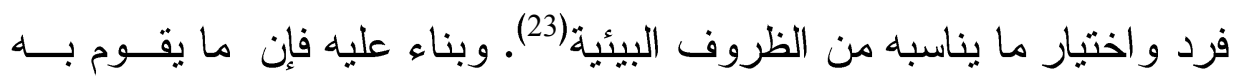

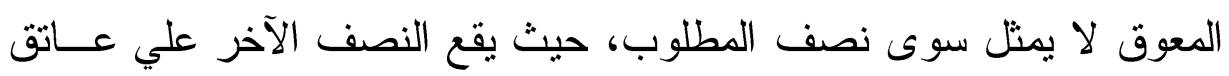

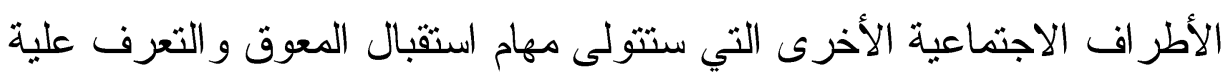
ويتطلب ذلك عدد من القضايا المرتبطة بقضية دمج المعوقين في المجتمع و هي الإني

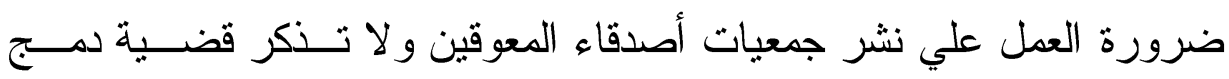

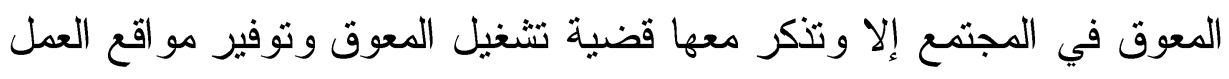

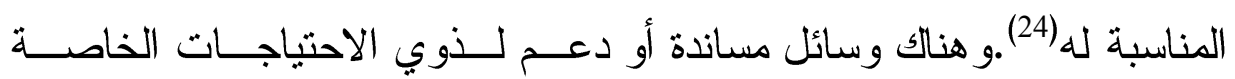

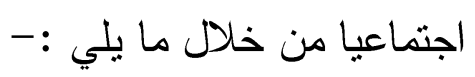




$$
\text { 3-1 - خدمات الإرشاد و التوجيه. }
$$

4- نظم خدمات المساندة المتبادلة أو التكاملية (25). • عينة البحث:

اشتثلت عينة البحث على عدد 300معاق ثم اختيار هم من المدارس ومر اكز

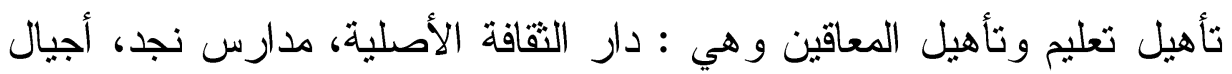

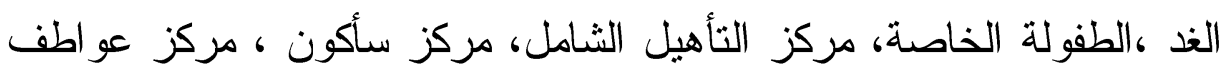
بن صديق لذوي الاحتياجات الخاصةهمركز الملك عبد الله (جمعيــة الأطفــال

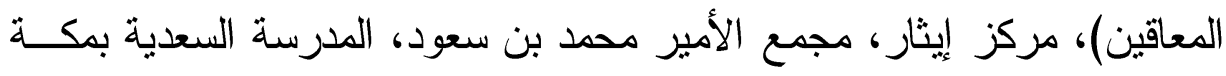

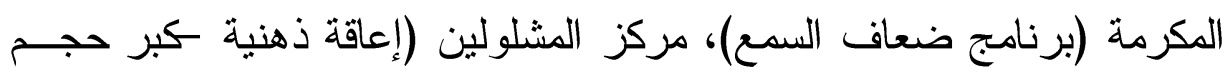

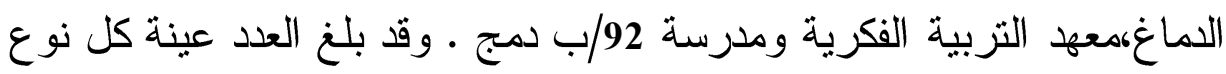
من أنو اع الإعاقات (60 من المعاقين ذهنيا ، 60 من المعاقين باضطر اب التوحد

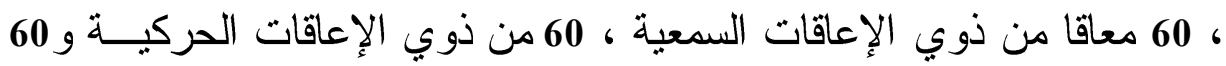

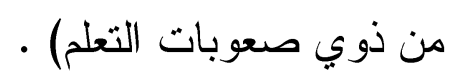
إعداد قائمة الحاجات النفسية والاجتماعية للمعاقين: قام الباحثان بإعداد قائمة باحتياجات طلاب المرحلة الثانوية للتوجيه التعليــي واجيه

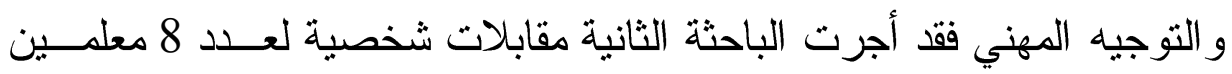

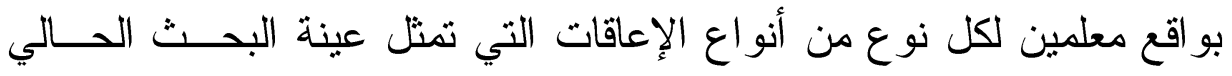
للتعرف علي احتياجات هؤلاء المعاقين النفسية و الاجتماعية كما قابلت معاقين

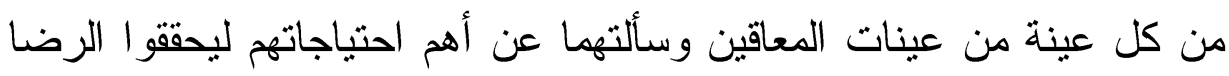
الذاتي و النو افق مع الآخرين وتقبل عن إعاقاتهم 


\section{•الار اسة الاستطلاعبة:}

تم إجراء دراسة استطلاعية بهاف حساب معاملي ثبات وصدق قائمة الاحتياجات النفسية والاجتماعية للمعاقين،ولأجل ذلك تم تطبيق القائمة علي عينة مكونة دن 50 معاق تم اختيار هم بطريقة عشو ائية المعاق ذهنيا ، 10

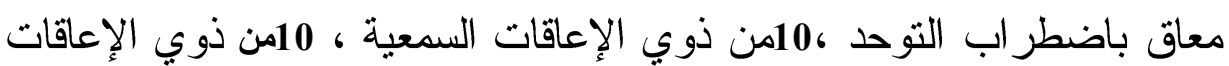

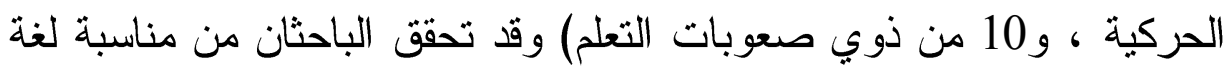

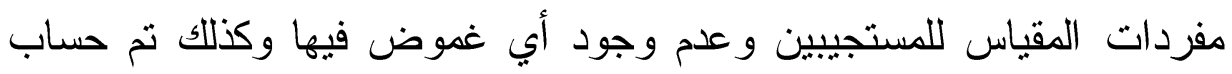
زمن تطبيق المقياس بو اسطة الباحثة الثانية التي طبقت القائمة علي عينات

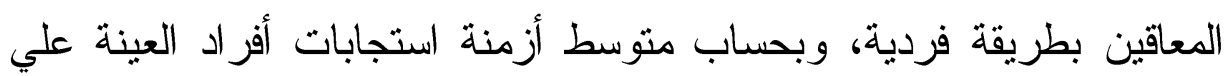
بنود المقياس وكانت قيمته 28,54 دقيقة بانحر اف معياري قدره 2,12 وبذلك تم تحديد زمن تطبيق المقياس بوقت مقداره 30 دقيقة .

أولال- الثبات: Reliability

تم التحقق من ثبات المقياس بطريقة إعادة التطبيق Test-retest: معامل الاستقرار(Stability) حيث تم تطبيق المقياس على أفراد عينة الدراسة الاستطلاعية، و أعيد التطبيق على الطلبة أنفسهم بعد فترة 21 يوما، وباستخدام معامل ارتباط يرسون Pearson بين درجات التطبيقين الأول و الثاني كانت

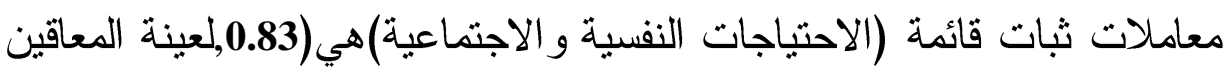
ذهنيا، 0.81 لعينة المعاقين باضطر اب التوحد ، 0.76 ، 0.82 لعينة المعاقين

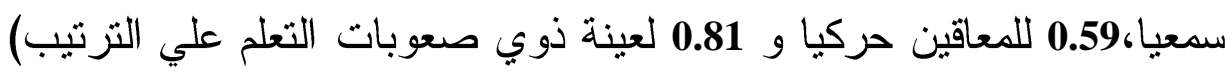

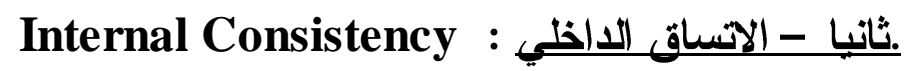

تم حساب معاملات الارتباط بين كل مفردة من قائمة الاحتياجات النفسـية

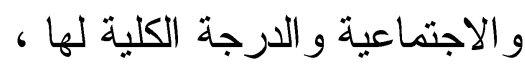
هذا ويوضح الجدول (2) معاملات الارتباط بين درجات أفر اد عينة البحث في ولائه قائمة الحاجات للتوجيه المهني و الدرجة الكلية للقائمة: 
جدول رقم (2): معاملات الارتباط بين مفردات قائمة الحاجات النفسية والاجتماعية و الارجة الكلية لله

\begin{tabular}{|c|c|c|c|}
\hline معاملات الارتباط & رقم البند & معاملات الارتباط & رقم البند \\
\hline 0,765 & 31 & 0,866 & 1 \\
\hline 0,852 & 32 & 0,7 & 2 \\
\hline $\mathbf{0 , 7 3 1}$ & 33 & $\mathbf{0 , 8 9 1}$ & 3 \\
\hline 0.740 & 34 & $\mathbf{0 , 8 5 5}$ & 4 \\
\hline 0.599 & 35 & 0,823 & 5 \\
\hline 0.665 & 36 & 0,688 & 6 \\
\hline 0.817 & 37 & 0,855 & 7 \\
\hline 0.833 & 38 & 0,784 & 8 \\
\hline 0.715 & 39 & 0,634 & 9 \\
\hline 0.722 & 40 & 0,914 & 10 \\
\hline 0.696 & 41 & 0,756 & 11 \\
\hline 0.821 & $\overline{42}$ & 0,732 & 12 \\
\hline 0.693 & 43 & 0,864 & 13 \\
\hline 0.717 & $\overline{44}$ & 0,766 & 14 \\
\hline 0.826 & 45 & 0,757 & 15 \\
\hline 0.911 & 46 & 0,749 & 16 \\
\hline 0.766 & 47 & 0,834 & 17 \\
\hline $\mathbf{0 , 7 3 5}$ & 48 & 0,729 & 18 \\
\hline 0,791 & 49 & 0,744 & 19 \\
\hline $\mathbf{0 , 8 3 1}$ & 50 & 0,799 & 20 \\
\hline 0,755 & 51 & $\mathbf{0 , 8 7}$ & 21 \\
\hline 0,702 & 52 & 0,68 & 22 \\
\hline 0,689 & 53 & 0,75 & 23 \\
\hline 0,712 & 54 & $\mathbf{0 , 8 2}$ & 24 \\
\hline 0,891 & 55 & 0,76 & 25 \\
\hline 0,743 & 56 & $\mathbf{0 , 7 2}$ & 26 \\
\hline 0,811 & 57 & 0,77 & 27 \\
\hline $\mathbf{0 , 9 1 3}$ & 58 & 0,69 & 28 \\
\hline 0,876 & 59 & $\mathbf{0 , 8 1}$ & 29 \\
\hline $\mathbf{0 , 8 1 9}$ & 60 & 0,76 & 30 \\
\hline
\end{tabular}

يتضح من الجدول (2) أن جميع معاملات الارتباط بين مفردات قائمة الحاجات النفسية و الاجتماعية والدرجة الكلية له مرتفعة مما يؤكد علي اتساق القائمة وتماسكها، كما أن هذه المعاملات المرتفعة تؤكد علي أن مفردات هذه القائمة صادقة . 
ثثالثا: الصدق :

تم التحقق من صدق المحكمين حيث تم عرض القائمة علي عدد 10محكمين

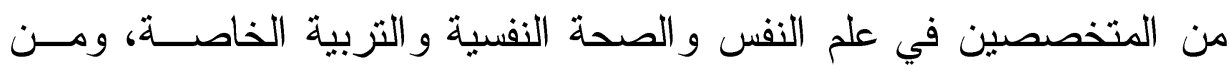

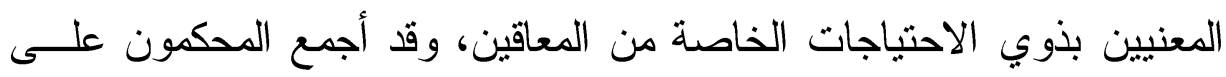

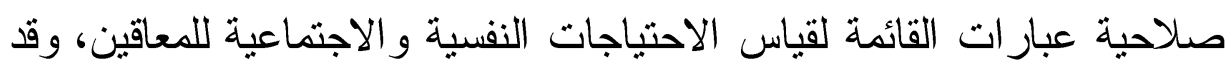

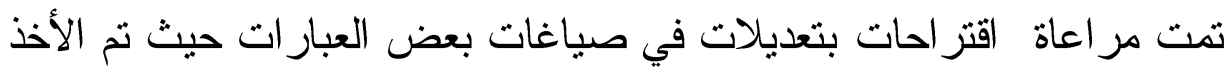

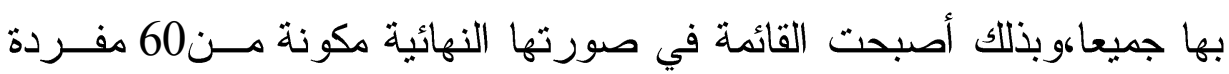

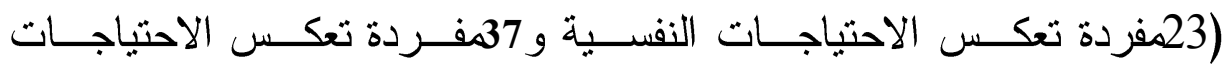

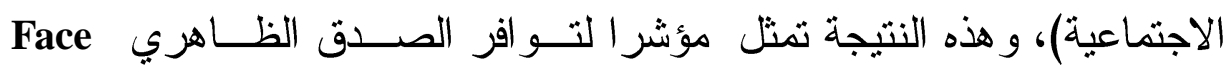
Validity

\section{•تطبيق القائمة والنتائج:}

طبقت القائمة بشكل فردي على عينة البحث من المعاقين الذين يمتلون عينة

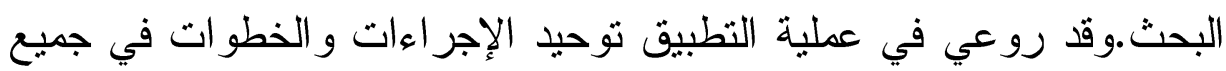
المدارس؛ حيث كانت هناك تعليمات مكتوبة تبين البيانات التي يجب توضيحها في عملية التطبيق، مثل اسم المدرسة أو المركز ونوع الإعاقة.

\section{•نتائيج اللار (سة :}

نم تطبيق القائمة بطريقة فردية، وقد روعي في عملية التطبيق توحيد الإجر اءات و الخطو ات في جميع المدارس أو المر اكز ؛حيث كانت هناك تعليمات فئه مكتوبة للمعلمين تبين لهم المتغيرات التي يجب مر اعاتها في عملية التطبيق، وكتابة بعض البيانات الأولية مثل اسم المعاق ودرجة إعاقته،.وقد تم تقدير درجات استجابات أفراد عينة البحث علي كل مفردة من مفردات قائمة الاحتياجات من4 درجات (4 درجات لدائما، 3 درجات لأحيانا ودرجتان لنادر البنات ودرجة واحدة لمطلقا) وتم حساب الأوزان النسبية لكل عبار ات القائمة التي

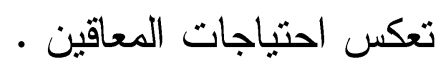


وقد قام الباحثان بتقدير درجات استجابات أفراد عينة البحث في المفردات الخاصة باحتياجات المعاقين وحساب الوزن النسبي لها وذلك بتقدير درجة دائما

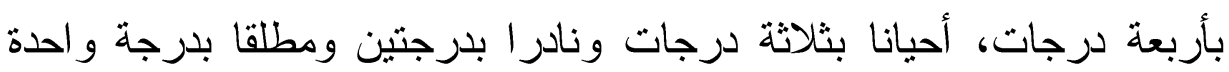
وبذلك تتر اوح درجات قائمة الاحتياجات النفسية بدرجة تنز اوح بين 23 درجة و 92 درجة كما تتزاوح درجات قائمة الاحتياجات الاجتماعية بين 37 و 148درجة .

الحاجات النفسية للمعاقين ذهنيا : النهات للتعرف علي أهم الحاجات النفسية للمعاقين ذهنيا ، تم حساب المأبن الأوزان انسبية لمفردات قائمة الحاجات النفسية للمعاقين ورتب هذه المفردات ترتيبا تتازليا ، و الجدول (3) يبين الأوزان النسبية لعبار ات الاحتياجات النفسية للمعاقين ذهنيا • كما يوضح جدول (4) الأوزان النسبية لعبارات الاحتياجات الاجتماعية للمعاقين ذهنيا و وترتيب كل منها تتازليا . جدول (3) : الحاجات النفسية للمعاقين ذهنيا والأوزان النسبية لها والترتيب التنازلي لـذه الحاجات

\begin{tabular}{|c|c|c|c|}
\hline التنازليب & النسبب & 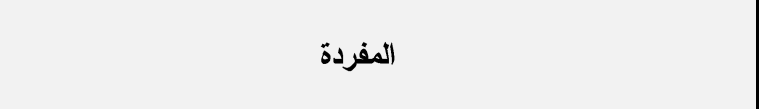 & رالمفردة \\
\hline 14 & 64 & | اكتساب الثقة بالنفس لتلافي الثعور بالنقص بسبب الإعاقة & 1 \\
\hline 1 & 89 & إظهار جوانب القوة لاي المعاق لتفادي نظرة الناس السالبة نحوه & 2 \\
\hline 2 & 87 & علاج المعاق من الثعور بالاكتئاب & 3 \\
\hline 6 & 75 & من يؤنس وحدة المعاق حتي لا يشعر بالنبذ & 4 \\
\hline 22 & 56 & | تكوين علاقات طيبة بين المعاق و الآخرين & 5 \\
\hline 13 & 65 & |الإرشاد النفسي للتقليل من إحساس المعاق بالفثل نتيجة لعجزه & 6 \\
\hline 11 & 66 & | من يساعد المعاق علي أن يشعر بذاته & 7 \\
\hline 11 & 66 & من يساعد المعاق علي تقبل ذاته كما هي & 8 \\
\hline 10 & 68 & من بساء المعاق علي التعامل بفاعلية مع الآخرين & 9 \\
\hline 3 & 85 & أن يفهم الآخرين طبيعة المعاق فهما صديحا & 10 \\
\hline 4 & 81 & تدريب المعاق علي تحديد أهداف مستقبلية لحياته & 11 \\
\hline 14 & 64 & | من يتعاطفون مع ظروف إعاقة الثخص المعاق & 12 \\
\hline
\end{tabular}


مجلة الدراسات التريويتّو الاسانية ـ كلية التربية ـ جامعة دمنهور - المجلا الخامس العدد (1) لسنة 2013

\begin{tabular}{|c|c|c|c|}
\hline التنازتيب & النسبي & 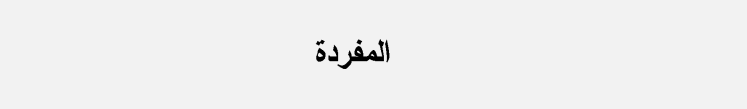 & رالمفردة \\
\hline 8 & 71 & من يتقبل المعاق كما هوعليه ألان حتي لا يفقد الثقة في نفسه & 13 \\
\hline 17 & 62 & مساعدة المحيطين بالمعاق لكي ينجح في دراسته & 14 \\
\hline 5 & 76 & من يرفع من روحه المعنوية حتي لا يفق الأمل في الحياة & 15 \\
\hline 19 & 58 & إحصائي نفسي يساعده علي حل مشكلاته & 16 \\
\hline 16 & 63 & تو افر رعاية طبية مناسبة للمعاق & 17 \\
\hline 18 & 61 & متابعة دورية لحالة المعاق الصحية & 18 \\
\hline 19 & 58 & ملاعب تصلح لممارسة المعاق للأنشطة الرياضية & 19 \\
\hline 17 & 60 & حائق يمكن لمعاق التنزه فيها & 20 \\
\hline 21 & 59 & من يساعد المعاق علي تدعيم الجوانب الايجابية في شخصيته & 21 \\
\hline 7 & 73 & وسائل تسلية وترفيه تساعد المعاق علي شغل أوقات فراغه فيها & 22 \\
\hline 9 & 69 & عدم تعبير الناس عن شفقتهم علي المعاق & 23 \\
\hline
\end{tabular}

يتضح من جدول (3) أن أهم10 حاجات نفسية للمعاقين ذهنيا مرتبة تنازليا هي:

1 - إظهار جو انب القوة لدي المعاق لتفادي نظرة الناس السالبة نحوه.

$$
2 \text { - العلاج من الثعور بالاكتئاب. }
$$

$$
3 \text { - أن يفهه الآخرين فها صحيحا . }
$$

4 - التدريب علي تحديد أهداف مستقبلية لحياته

5 - من يرفع من روحه المعنوية حتي لا يفقد الأمل في الحياة

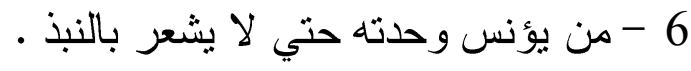

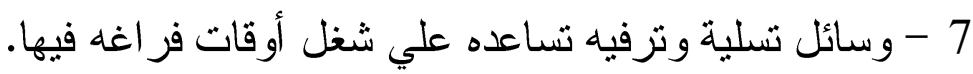

- 8 - هن يتقبله كما هو عليه ألان حتي لا يفقد الثقة في نفسه .

9- عدم تعبير الناس عن شفقته علي المعاق ذهنيا .

10 - من يساعده علي التعامل بفاعلية مع الآخرين .

و الاحتياجات النفسية العشرة المهمة للمعاقين ذهنيا تدور حول عجز الهرين المعاق ذهنيا لمهار ات التو اصل الاجتماعي و إحساسه بالدونية وعدم تقبل الآخرين له 
بالإضافة إلي عدم قدرته علي تحديد أهدافه المستقبلية وويمكن ثلبية هذه

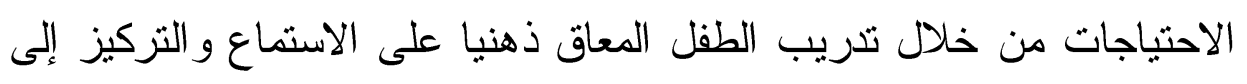
ما يقال له أويشاهده، السماح لله بالأسئلة في المواقف الاجتماعية بطريقة

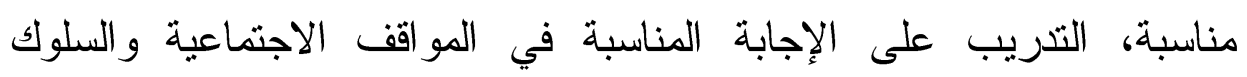

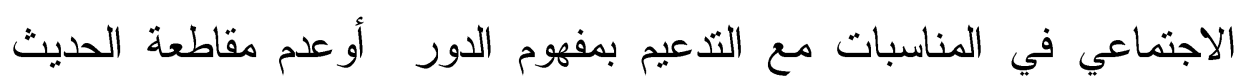

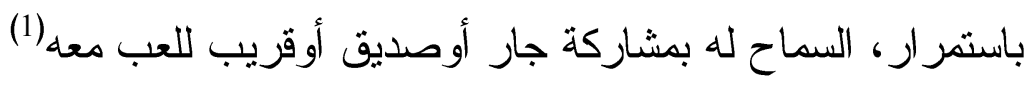

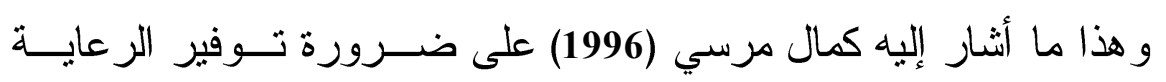

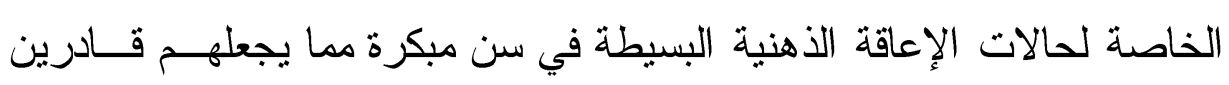

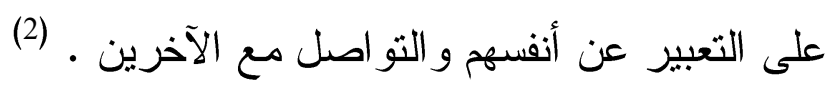
ويعرف كل من " كومبس " Combs و" سلابي " Slaby (1977) المهار ات

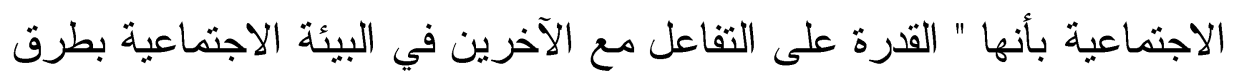

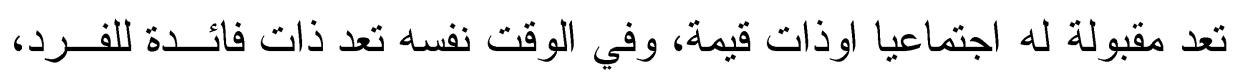

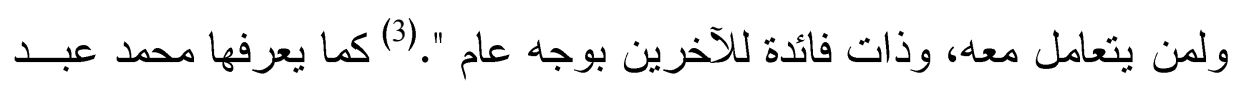

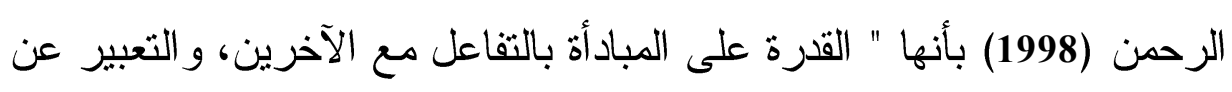

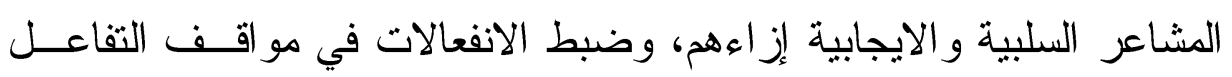

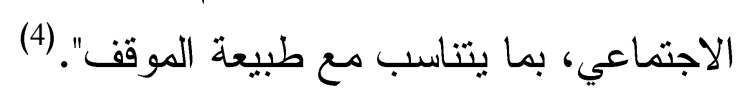

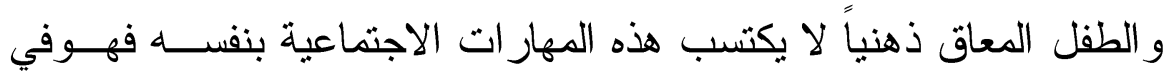

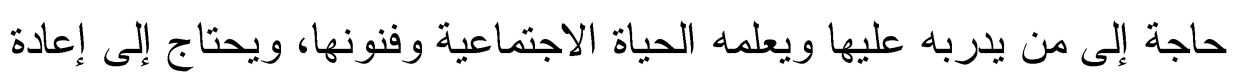

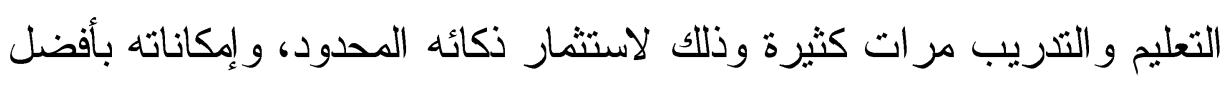
طريقة، والى أقصى حد مدكن محقق اكبر قدر من التكيف الاجتماعي يساعده

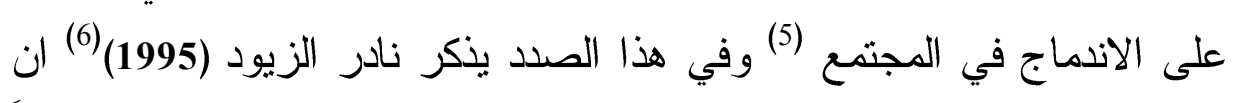
ممارسة الأنشطة الترويحية من الأمور الهامة في حياة الأطفال المعاقين ذهنياً

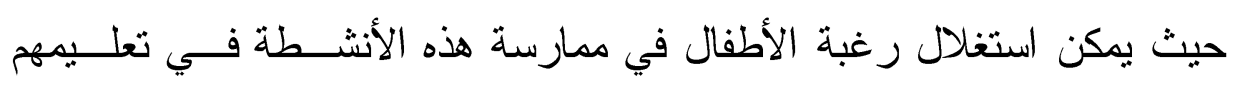

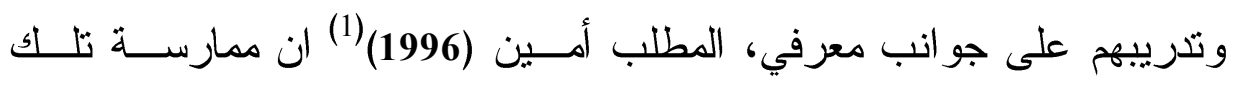


الأنشطة تساعد المعاقين ذهنياً على اكتساب العديد من المهار ات لشغل أوقات

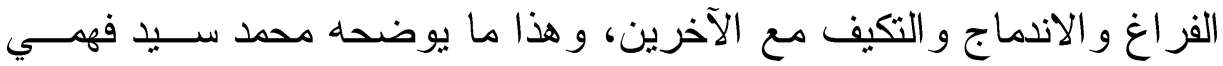

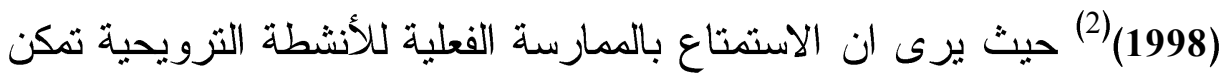

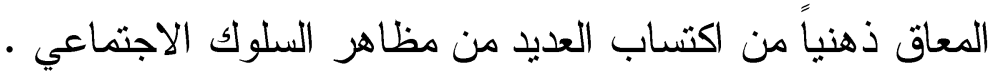
وبناءً على ذلك فقد أكد كل من تهاني عبد السلام (1993)، حلمي ابر اهيم، ليلى فرحات (1998) ان الجانب الترويحي حق أنساني للمعاقين،ويعد وســيلة ناجحة للترويح النفسي للمعاق فهويكسبه خبرات تساعده على التمتع بالحيــاة

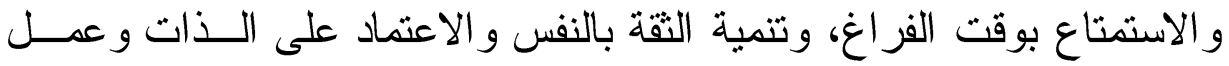

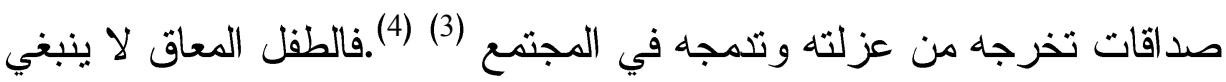

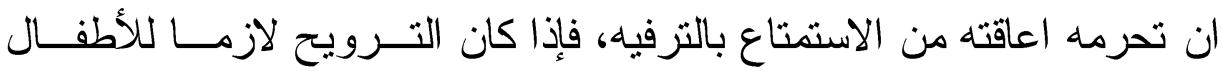

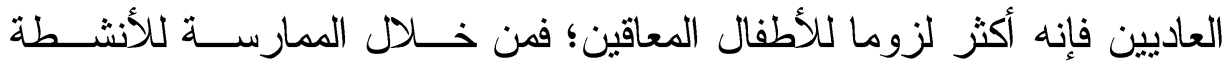

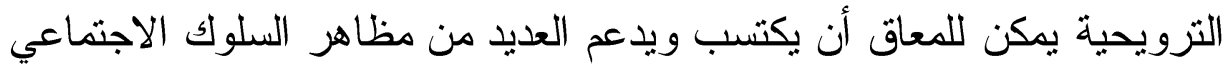

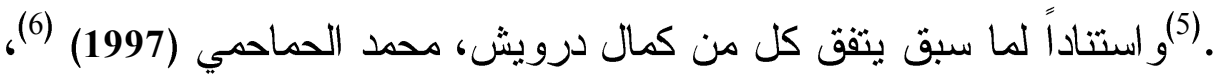
حلمي إير اهيم وليلى فرحات (1998) (7)، تهاني عبد السلام (2001) (8) على أن أن

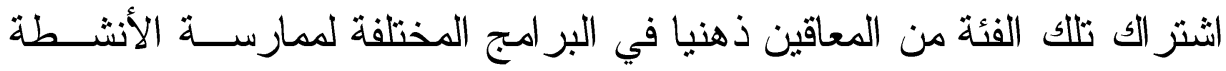

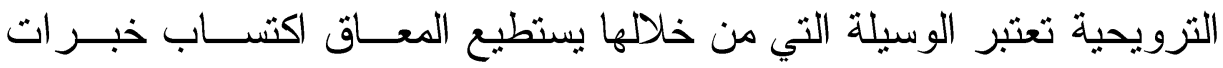

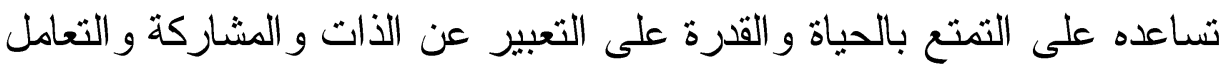
مع الآخرين و الثعور بالاطمئنان ورفع الروح المعنوية و الثقة بالنفس .

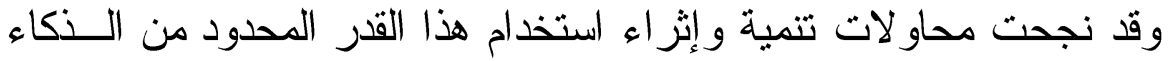

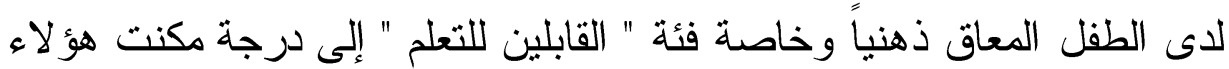
الأطفال من إن يعيشو ا حياة اقرب ما تكون الى الطبيعية، و هذا ما أكدته نتائج

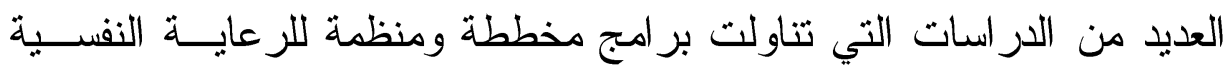

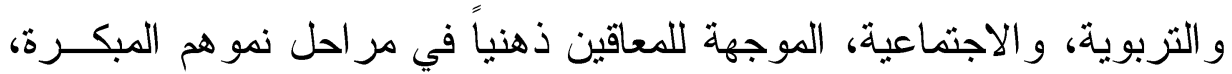

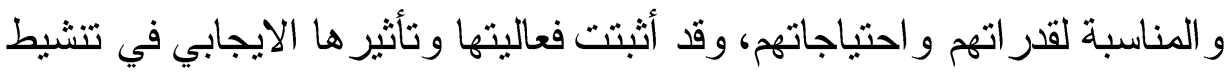




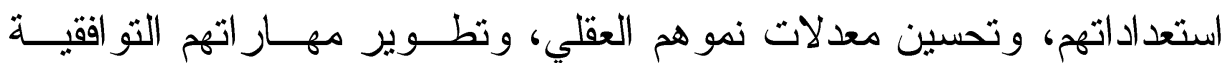

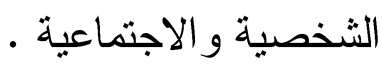
الحاجات الاجتماعية للمعاقين ذهنيا:

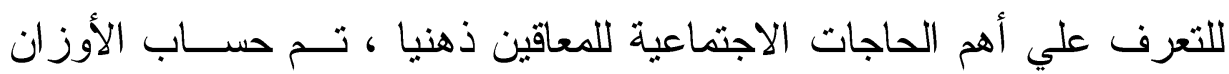

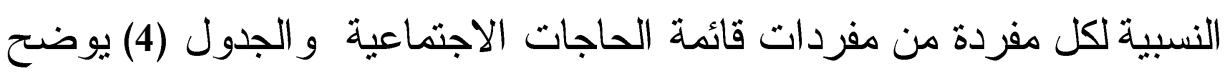
نتائج هذا الحساب

جدول (4) : الحاجات الاجتماعية للمعاقين ذهنيا والأوزان النسبية لها و الترتيب التنازلي لهذه الحاجات

\begin{tabular}{|c|c|c|c|}
\hline 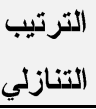 & 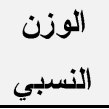 & 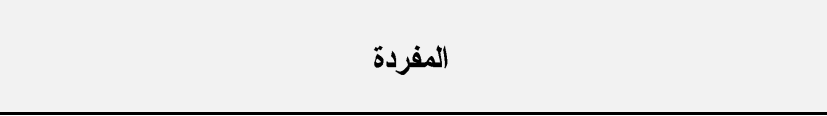 & 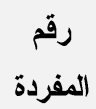 \\
\hline 15 & 102 & إن يحترم الآخرين المعاق ولا يسحرون منه & 24 \\
\hline 12 & 110 & أن يجد المعاق من يلعب معه في أوقات فراغه & 25 \\
\hline 25 & 82 & أن يحصل المعاق علي خلمات خاصة لتسهيل تدركاته & 26 \\
\hline 17 & 98 & توفير رحلات ترفيهية أكثر للمعاقين & 27 \\
\hline 26 & 80 & توفير إحصائي اجتماعي قادر علي فهم ظروف المعاق واحتياجاته & 28 \\
\hline 35 & 65 & أن يتقبل الآخرين المعاق للعمل معهم كأحد أعضاء الفريق الذي يخصهم & 29 \\
\hline 33 & 66 & زيارة الآخرين للمعاق & 30 \\
\hline 2 & 130 & مشاركة المعاق في أنشطة اجتماعية مع الآخرين & 31 \\
\hline 17 & 98 & أن لا يشعر المعاق بأنه يسبب أي مشكلات بين و الديه. & 32 \\
\hline 22 & 85 & أن لا ينبذ الآخرين المعاق بسبب إعاقته & 33 \\
\hline 6 & 123 & أن لا يشعر المعاق بأن و الايه يخجلون من إعاقته & 34 \\
\hline 4 & 128 & تنمية مهارات التواصل بين المعاق والآخرين & 35 \\
\hline 9 & 117 & تنمية مهارات المعاق علي اتخاذ القرارات المناسبة & 36 \\
\hline 7 & 121 & تنمية مهارات المعاق علي تكوين علاقات اجتماعية ناجحة مع الاخربن & 37 \\
\hline 21 & 86 & إتاحة الفرص التعليمية أمام المعاق للاراسة والتعليم & 38 \\
\hline 9 & 117 & إلأتاحة الفرص التي تساعد المعاق علي تكوين مجموعـات جديــة مـن & 39 \\
\hline 33 & 66 & من يساعد المعاق علي ارتداء ملابسه & 40 \\
\hline 29 & 76 & من يساعد المعاق علي معرفة كيفية تناول الطعام & 41 \\
\hline 19 & 96 & تعلم كيفية الاستحمام بدون مساعدة من احد & 42 \\
\hline
\end{tabular}


مجلة الدراسات التريويتّو الاسانية ـ كلية التربية ـ جامعة دمنهور - المجلا الخامس العدد (1) لسنة 2013

\begin{tabular}{|c|c|c|c|}
\hline 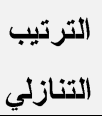 & 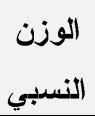 & 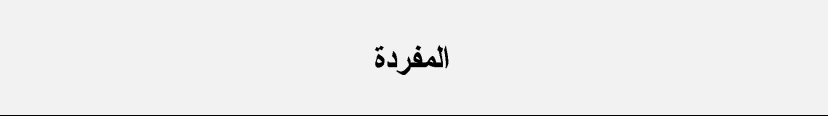 & 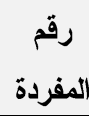 \\
\hline 27 & 79 & تعلم كيفية ممارسة سلوك النظافة الثخصية اليومية & 43 \\
\hline 36 & 59 & تعلم كيفية استخذام الأطراف الصناعية استخذ(ما صحيحا & 44 \\
\hline 30 & 73 & تدريب المعاق علي كيفية ارتاء الدذاء بمفردة & 45 \\
\hline 13 & 108 & تدريب المعاق علي ممارسة بعض التمرينات الرياضية المناسبة & 47 \\
\hline 20 & 88 & تدريب المعاق علي صعود وهبوط السلم بمفرده & 48 \\
\hline 14 & 105 & تعلم المعاق كيفية عبور الطريق بمفرده & 49 \\
\hline 16 & 99 & تدريب المعاق علي كيفية حماية نفسه عند الضرورة & 50 \\
\hline 24 & 81 & تدريب المعاق علي تحمل المجهود العضلي & 51 \\
\hline 28 & 77 & تدريب المعاق علي كيفية الحصول علي بعض الأثشياء التي توجـــــــي & 52 \\
\hline 36 & 65 & توفير العلاج الطبي المجاني ياستمرا & 53 \\
\hline 1 & 138 & تدريب المعاق علي اكتساب المهارات اللازمة للعمل بمهنة المستقبل & 54 \\
\hline$\overline{8}$ & 120 & توفير حاسوب و التّريب علي استخدامه & 55 \\
\hline 37 & 53 & توفير أجهزة تعويضية مناسبة لطبيعة الإعاقة & 56 \\
\hline 3 & 129 & إتاحة فرص عمل مناسبة لطبيعة حالة المعاق & 57 \\
\hline 11 & 111 & توفير مشرف اجتماعي يتفه حالة المعاق & 58 \\
\hline 9 & 119 & إتاحة فرص للمعاق للحصول علي مسكن خاص به في المستقبل & 59 \\
\hline 5 & 124 & تلتوفير وسائل مواصلات مجانية تساعد المعاق علي الوصــول للأمـاكن & 60 \\
\hline
\end{tabular}

يتضح من الجدول (4) ان أهم 10 احتياجات اجتماعية للمعاقين ذهنيا هي علي

التزتيب :

1- التدريب علي اكتساب المهار ات اللازمة للعمل بمهنة المستقبل

2-مشاركة المعاق في أنشطة اجتماعية مع الآخرين

3- إتاحة فرص عمل مناسبة لطبيعة حالة المعاق

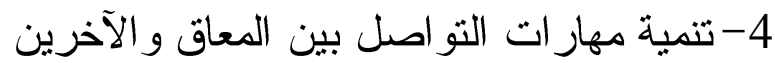

5- توفير وسائل مو اصلات مجانية تساعده علي الوصول للأكاكن التي يريدون

الوصول إليها. 
6- أن لا يشعر المعاق بأن و الديه يخجلون من إعاقته .

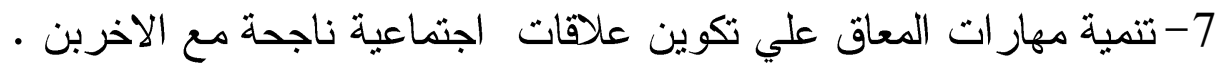

8-توفير حاسوب وتثريب المعاق علي استخدامه.

9-تنمية مهار ات المعاق علي اتخاذ القرار ات المناسبة.

10- إتاحة الفرص التي تشاعد المعاق علي تكوين مجموعــات جديـدة مــن

$$
\text { الأصدقاء. }
$$

\section{الحاجات النفسية لذوي اضطراب التوحد :}

تم حساب الأوزان النسبية لكل فقرة من فقرة من فقرات قائمة تقدير الحاجات

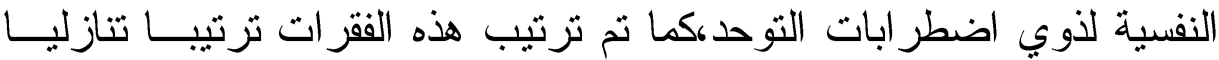

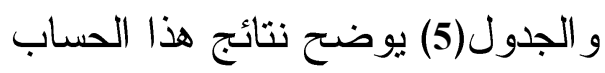

جدول (5) : الحاجات النفسية لذوي اضطراب التوحد والأوزان النسبية لها والترتيب

\begin{tabular}{|c|c|c|c|}
\hline الترتيب & النوزن & 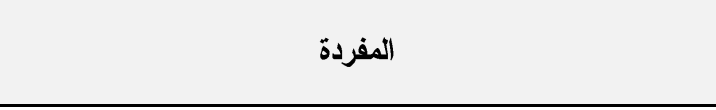 & رقم \\
\hline 11 & 77 & اكتساب الثقة بالنفس لتلافي الثعور بالنقص بسبب الإعاقة & 1 \\
\hline 8 & 80 & نـوه إظهار جوانب القوة لدي المعاق لتفادي نظرة النــاس الســالبة & 2 \\
\hline 4 & 83 & العلاج من الشعور بالاكتئاب & 3 \\
\hline $\mathbf{1 0}$ & 78 & من يؤنس وحدة المعاق حتي لا يشعر بالنبذ & 4 \\
\hline 23 & 59 & تكوين علاقات طيبة بين المعاق والآخرين & 5 \\
\hline 6 & 81 & لإلعجزهاد النفسي للتقليل من إحساس المعــاق بالفشـلـل نتيجــة & 6 \\
\hline 4 & 83 & من يساعد المعاق عثي أن يشعر بذاته & 7 \\
\hline 8 & 80 & من يساعد المعاق علي تقبل ذاته كما هي & 8 \\
\hline 2 & 86 & من يساعد المعاق علي التعامل بفاعلية مع الآخرين & 9 \\
\hline 15 & 71 & أن يفهم الآخرين طبيعة المعاق فهما صحيحا & 10 \\
\hline 20 & 63 & تدريب المعاق علي تحيد أهداف مستقبلية لحياته & 11 \\
\hline 2 & 86 & من يتعاطفون مع ظروف إعاقة المعاق & 12 \\
\hline
\end{tabular}

التنازلي لهذه الحاجات 
مجلة الدراسات التريويتّو الاسانية ـ كلية التربية ـ جامعة دمنهور - المجلا الخامس العدد (1) لسنة 2013

\begin{tabular}{|c|c|c|c|}
\hline 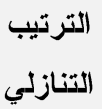 & 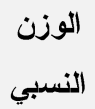 & 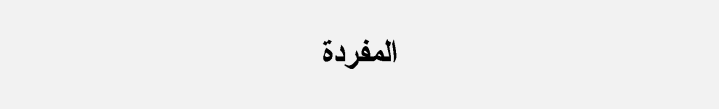 & 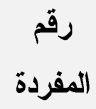 \\
\hline 13 & 75 & من يتقبل المعاق كما هوعليه ألان حتي لا يفقد الثقة في نفسه & 13 \\
\hline 18 & 67 & مساعدة المحيطين بالمعاق لكي ينجح في دراسته & 14 \\
\hline 6 & 81 & من يرفع من روح المعاق المعنوية حتي لا يفقـــ الأمـلـل فـي & 15 \\
\hline 1 & 88 & إخصائي نفسي يساعد المعاق علي حل مشكلاته & 16 \\
\hline 14 & 74 & تو افر رعاية طبية مناسبة للمعاق & 17 \\
\hline 17 & 68 & متابعة دورية لحالة المعاق الصحية & 18 \\
\hline 22 & 59 & ملاعب تصلح لممارسة المعاق للأنشطة الرياضية & 19 \\
\hline 16 & 70 & حدائق يمكن للمعاق التنزه فيها & 20 \\
\hline 19 & 64 & شخصيته يساعد المعاق علــي تــــعيم الجوانــب الايجابيـة فــي & 21 \\
\hline 20 & 63 & فيهائل تسلية وترفيه تساع المعاق علي شغل أوقات فراغـهـ & 22 \\
\hline 12 & 76 & عدم تعبير الناس عن شفقتهم علي المعاق . . & 23 \\
\hline
\end{tabular}

يتضح من الجدول (5) إن أهم 10 عثرة احتياجات نفسية لذوي اضطر اب التوحد هي علي الترتيب: 1 - إخصائي نفسي يساعد المعاق علي حل مشكلاته . 2-من يتعاطفون مع ظروف إعاقة المعاق. 3-من يساعد المعاق علي التعامل بفاعلية مع الآخرين. 4- دن يساعد المعاق علي أن يشعر بذاته. 5- علاج المعاق دن الشعور بالاكثئاب.

6-من يرفع من روح المعاق المعنوية حتي لا يفقد الأمل في الحياة . 7- الإرشاد النفسي للتقليل من إحساس المعاق بالفشل نتيجة عجزه . 8-من بساعد المعاق علي تقبل ذاته كما هي 9- إظهار جوانب القوة لدي المعاق لتفادي نظرة الناس السالبة نحوه. 
10-من يؤنس وحدة المعاق حتي لا يشعر بالنبذ.

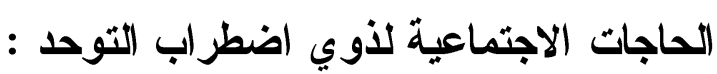

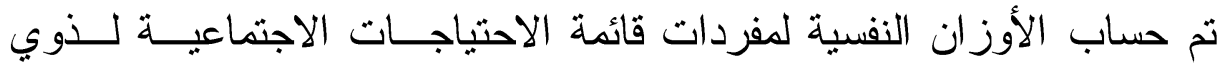
اضطر اب التوحد ـ ثم تم ترتيب الفقرات ترتيبا تتازليا حسب أهميتها و الجدول

(6) يبين نتائج هذا الحساب

جدول (6) : الحاجات الاجتماعية لذوي اضطراب التوحد والأوزان النسبية لها والترتيب التتازلي لهذه الحاجات

\begin{tabular}{|c|c|c|c|}
\hline التنازليب & النسبي & المفردة & رقمر \\
\hline 21 & 98 & إن يحترم الآخرين المعاق ولا يسحرون منه & 24 \\
\hline 8 & 131 & أن يجد المعاق من يلعب معه في أوقات فراغه & 25 \\
\hline 26 & 72 & أن يحصل المعاق علي خلمات خاصة لتسهيل تحركاته & 26 \\
\hline 20 & 109 & توفير رحلات ترفيهية أكثر للمعاقين & 27 \\
\hline 2 & 152 & وتوفير إحصائي اجتماعي قادر علي فهم ظروف المعاق & 28 \\
\hline 18 & 112 & أن يتقبل الآخرين المعاق للعمل معهم كأحد أعضاء الفريق الأي & 29 \\
\hline 23 & 86 & زيارة الآخرين للمعاق & 30 \\
\hline 7 & 139 & مشاركة المعاق في أنشطة اجتماعية مـع الآخرين & 31 \\
\hline 3 & 147 & أن لا بشعر المعاق بأنه يسبب أي مشكلات بين و الايه. & 32 \\
\hline 22 & 95 & أن لا ينبذ الآخرين المعاق بسبب إعاقته & 33 \\
\hline 14 & 123 & أن لا يشعر المعاق بأن والايه يخجلون من إعاقته & 34 \\
\hline 11 & 128 & تنمية مهارات التواصل بين المعاق والآخرين & 35 \\
\hline 16 & 117 & تنمية مهارات المعاق علي اتخاذ القرارات المناسبة & 36 \\
\hline 15 & 121 & تآنمية مهارات المعاق علي تكوين علاقات اجتماعية ناجحة مع & 37 \\
\hline 23 & 86 & إتاحة الفرص التعليمية أمام المعاق للاراسة و التعليم & 38 \\
\hline 16 & 117 & من إتاحة الفرص التي تساعد المعاق علي تكوين مجموعات جليدة & 39 \\
\hline 31 & 38 & من يساعد المعاق علي ارتداء ملابسه & 40 \\
\hline 33 & 37 & من يساعد المعاق علي معرفة كيفية تناول الطعام & 41 \\
\hline
\end{tabular}


مجلة الدراسات التريويتّو الاسانية ـ كلية التربية ـ جامعة دمنهور - المجلا الخامس العدد (1) لسنة 2013

\begin{tabular}{|c|c|c|c|}
\hline التنازليب & 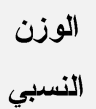 & 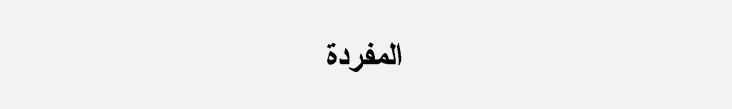 & المفردة - مقا \\
\hline 27 & 63 & تعلم كيفية الاستحمام بدون مساعدة من احد & 42 \\
\hline 30 & 53 & تعلم كيفية ممارسة سلوك النظافة الثخصية اليومية & 43 \\
\hline 33 & 37 & تعلم كيفية استذام الأطر اف الصناعية استخذاما صحيحا & 44 \\
\hline 31 & 48 & تدريب المعاق علي كيفية ارتداء الحذاء بمفردة & 45 \\
\hline 4 & 143 & تدريب المعاق علي ممارسة بعض التمرينات الرياضية المناسبة & 47 \\
\hline 31 & 38 & تدريب المعاق علي صعود وهبوط السلم بمفرده & 48 \\
\hline 25 & 82 & تعلم المعاق كيفية عبور الطريق بمفرده & 49 \\
\hline 6 & 140 & تدريب المعاق علي كيفية حماية نفسه عند الضرورة & 5 \\
\hline 19 & 111 & تدريب المعاق علي تحمل المجهود العضلي & 51 \\
\hline 28 & 60 & توريب المعاق علي كيفية الحصول علي بعض الأشياء التي & 52 \\
\hline 29 & 57 & توفير العلاج الطبي المجاني ياستمرا & 53 \\
\hline 8 & 131 & تلدريب المعاق علي اكتسلب المهارات اللازمة للعمل بمهنة & 54 \\
\hline 1 & 160 & توفير حاسوب و التذريب علي استخذامه & 55 \\
\hline 33 & 37 & توفير أجهزة تعويضية مناسبة لطبيعة الإعاقة & 56 \\
\hline 5 & 141 & إتاحة فرص عمل مناسبة لطبيعة حالة الدعاق & 57 \\
\hline 13 & 125 & توفير مشرف اجتماعي يتفهم حالة المعاق & $\begin{array}{l}58 \\
\end{array}$ \\
\hline 10 & 129 & إتاحة فرص للمعاق للحصول علي مسكن خاص به في & 59 \\
\hline 11 & 128 & تلتيرير وسائل مواصلات مجانية تساعده علي الوصول للأماكن & 60 \\
\hline
\end{tabular}

يتضح من الجدول (6) أن أهم 10 حاجات اجتماعية للمعاقين باضطر اب ابل

$$
\text { التوحد هي علي الترتيب : }
$$

1- توفير حاسوب و التذريب علي استخدامه.

2- توفير إحصائي اجتماعي قادر علي فهم ظروف المعاق واحتياجاته . .

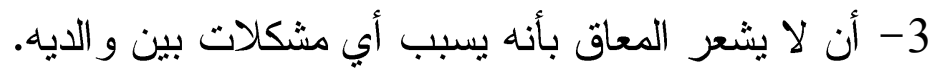

4- تدريب المعاق علي ممارسة بعض التمرينات الرياضية المناسبة. 
5- إتاحة فرص عمل مناسبة لطبيعة حالة المعاق.

6- تدريب المعاق علي كيفية حماية نفسه عند الضرورة.

7- مشاركة المعاق في أنشطة اجتماعية مع الآخرين.

8 - أن يجد المعاق من يلعب معده في أوقات فر اغهـ

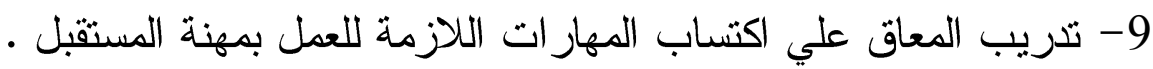

10- إتاحة فرص للمعاق للحصول علي مسكن خاص به في المستقبل .

الحاجات النفسية للمعاقين سمعيا : التهن

تم حساب الأوزان النسبية لقائمة الاحتياجات النفسية للمعاقين سمعيا والترتيب

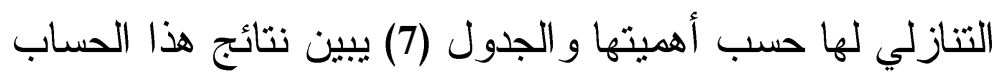


مجلة الدراسات التربيويتو الاسانية ـ كلية التربية ـ جامعة دمنهور - المجلد الخامس العدد (1) لسنة 2013

جدول (7) : الحاجات النفسية للمعاقين سمعيا والأوزان النسبية لها والترتيب التنازلي لهذه الحاجات

\begin{tabular}{|c|c|c|c|}
\hline الترتيب & النسبن & المفردة & رقمر \\
\hline $\mathbf{1}$ & 90 & اكتساب الثقة بالنفس لتلافي الثعور بالنقص بسبب الإعاقة & 1 \\
\hline 13 & 79 & إظهار جواتب القوة لاي المعاق لتفادي نظرة الناس السالبة نحوه & 2 \\
\hline 11 & 82 & العلاج من الشعور بالاكتئاب & 3 \\
\hline 17 & 78 & من يؤنس وحتته حتي لا يشعر بالنبذ & 4 \\
\hline 8 & 85 & تكوين علاقات طيبة بين المعاق والآخرين & 5 \\
\hline 6 & 86 & الإرشاد النفسي للتقليل من إحساس المعاق بالفشل نتيجة لعجزه & 6 \\
\hline 10 & 83 & من يساعد المعاق علي أن يشعر بذاته & 7 \\
\hline 16 & 79 & من يساعد المعاق علي تقبل ذاته كما هي & 8 \\
\hline 6 & 86 & من يساع المعاق علي التعامل بفاعلية مع الآخرين & 9 \\
\hline 11 & 82 & أن يفهم الآخرين طبيعة المعاق فهما صحيحا & 10 \\
\hline 13 & 81 & التدريب علي تحيد أهداف مستقبلية لدياته & 11 \\
\hline 23 & 63 & من يتعاطفون مع ظروف إعاقته & 12 \\
\hline 21 & 68 & من يتقبل المعاق كما هوعليه ألان حتي لا يفقد الثقة في نفسه & 13 \\
\hline $\mathbf{1}$ & 90 & مساعدة المحيطين بالمعاق لكي ينجح في دراسته & 14 \\
\hline 8 & 85 & من يرفع من الروح المعنوية للمعاق حتي لا يفقد الأمل في الحياة & 15 \\
\hline 4 & 88 & إخصائي نفسي يساعد المعاق علي حل مشكلاته & 16 \\
\hline 19 & 77 & توافر رعاية طبية مناسبة للمعاق & 17 \\
\hline 18 & 78 & متابعة دورية لحالة المعاق الصحية & 18 \\
\hline 22 & 67 & ملاعب تصلح لممارسة المعاقين للأنشطة الرياضية & 19 \\
\hline 5 & 87 & حدائق يمكن للمعاق التنزه فيها & 20 \\
\hline 16 & 80 & من يساعد المعاق علي تدعيم الجوانب الايجابية في شخصيته & 21 \\
\hline 3 & 89 & وسائل تسلية وترفيه تساع المعاق علي شغل أوقات فراغه فيها & 22 \\
\hline 20 & 74 & عدم تعبير الناس عن شفقتهم علي المعاق & 23 \\
\hline
\end{tabular}

يتضح من الجدول (7) أن أهم 10 احتياجات نفسية لذوي الإعاقات السمعية هي عي عيدي

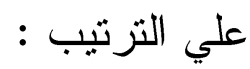
1-مساعدة المحيطين بالمعاق لكي ينجح في در استه. 
2- اكتساب الثقة بالنفس لتلافي الثعور بالنقص بسبب الإعاقة. 3-وسائل تسلية ونزفيه تساعد المعاق علي شغل أوقات فر اغه فيها. 4- إخصائي نفسي يساعد المعاق علي حل مشكلاته. 5-حدائق يمكن للمعاق التنزه فيها. 6- من يساعد المعاق علي التعامل بفاعلية مع الآخرين.

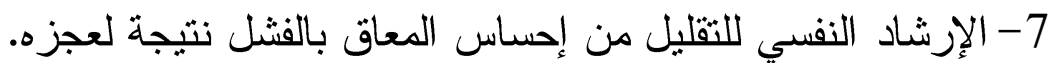
8-من يرفع من الروح المعنوية للمعاق حتي لا يفقد الأمل في الحياة. 9-تكوين علاقات طيبة بين المعاق و الآخرين. 10- إلي دن يساعد المعاق أن يشعر بذاته.

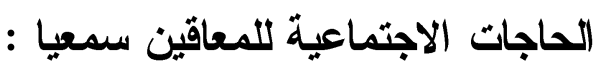
تم حساب الأوزان النسبية لقائمة الاحتياجات الاجتماعية للمعاقين سمعيا و الترتيب التنازلي لها حسب أهميتها و الجدول (8) يبين نتائج هذا الحساب الاحن جدول (8) : الحاجات الاجتماعية للمعاقين ذهنيا والأوزان النسبية لها والترتيب التنازلي لهابل

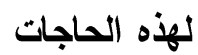

\begin{tabular}{|c|c|c|c|}
\hline التنازليب & 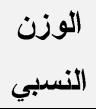 & 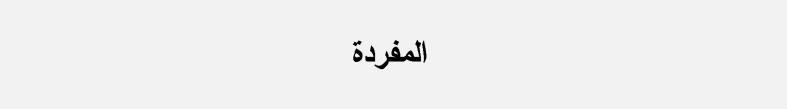 & 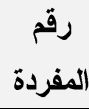 \\
\hline 6 & 133 & إن يحترم الآخرين المعاق ولا يسحرون منه & 24 \\
\hline 12 & 120 & أن يجد المعاق من يلعب معه في أوقات فراغه & 25 \\
\hline 25 & 92 & أن بحصل المعاق علي خدمات خاصة لتسهيل تحركاته & 26 \\
\hline 17 & 108 & توفير رحلات ترفيهية أكثر للمعاقين & 27 \\
\hline 26 & 90 & توفير إخصائي اجتماعي قادر علي فهم ظروف المعاق واحتياجاته & 28 \\
\hline 35 & 75 & أن يتقبل الآخرين المعاق للعمل معهم كأحد أعضاء الفريق الذي & 29 \\
\hline 33 & 76 & زيارة الآخرين للمعاق & 30 \\
\hline 7 & 131 & مشاركة المعاق في أنشطة اجتماعية مع الآخرين & 31 \\
\hline 17 & 108 & أن لا يشعر المعاق بأنه يسبب أي مشكلات بين والديه. & 32 \\
\hline 22 & 95 & أن لا ينبذ الآخرين المعاق بسبب إعاقته & 33 \\
\hline 15 & 112 & أن لا يشعر المعاق بأن و الديه يخجلون من إعاقته & 34 \\
\hline
\end{tabular}

doi : $10.12816 / 0001053$ 
مجلة الدراسات التريويتّو الاسانية ـ كلية التربية ـ جامعة دمنهور - المجلا الخامس العدد (1) لسنة 2013

\begin{tabular}{|c|c|c|c|}
\hline التنازليب & 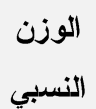 & 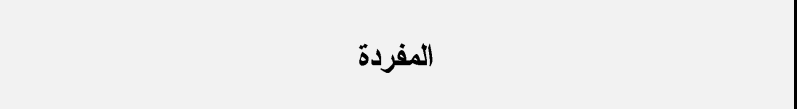 & 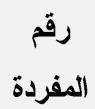 \\
\hline 4 & 138 & | تنمية مهارات التواصل بين المعاق والآخرين & 35 \\
\hline 9 & 127 & |تنمية مهارات المعاق علي اتخاذ القرارات المناسبة & 36 \\
\hline 2 & 140 & | تنمية مهارات المعاق علي تكوين علاقات اجتماعية ناجحة مع & 37 \\
\hline 21 & 96 & | إتاحة الفرص التعليمية أمام المعاق للاراسة و التعليم & 38 \\
\hline 9 & 127 & |الأتاحة الفرص التي تساءد المعاق علي تكوين مجموعات جديدة من & 39 \\
\hline 33 & 76 & | من يساعد المعاق علي ارتداء ملابسه & 40 \\
\hline 29 & 86 & |من يساعد المعاق علي معرفة كيفية تناول الطعام & 41 \\
\hline 19 & 109 & |تعلم كيفية الاستحمام بدون مساعدة من (حد & 42 \\
\hline 27 & 89 & | تعلم كيفية ممارسة سلوك النظافة الثخصية اليومية & 43 \\
\hline 36 & 69 & | تعلم كيفية استخدام الأطر اف الصناعية استخداما صديحا & 44 \\
\hline 30 & 83 & |تدريب المعاق علي كيفية ارتداء الحذاء بمفردة & 45 \\
\hline 13 & 118 & |تدريب المعاق علي ممارسة بعض التمرينات الرياضية المناسبة & 47 \\
\hline 20 & 98 & تدريب المعاق علي صعود وهبوط السلم بمفرده & 48 \\
\hline 14 & 115 & | تعلم المعاق كيفية عبور الطريق بمفرده & 49 \\
\hline 16 & 109 & |تدريب المعاق علي كيفية حماية نفسه عند الضرورة & 50 \\
\hline 24 & 101 & |تدريب المعاق علي تحمل المجهود العضلي & 51 \\
\hline 28 & 87 & | أماكن مرتفعة المعاق علي كيفية الحصول علي بعض الأشياء التي توجد في & 52 \\
\hline 36 & 75 & |توفير العلاج الطبي المجاني ياستمرا & 53 \\
\hline 1 & 148 & تلدريب المعاق علي اكتساب المهارات اللازمة للعمل بمهنة المستقبل & 54 \\
\hline 8 & 130 & |توفير حاسوب والتدريب علي استخدامه & 55 \\
\hline 37 & 63 & | توفير أجهزة تعويضية مناسبة لطبيعة الإعاقة & 56 \\
\hline 3 & 139 & | إتاحة فرص عمل مناسبة لطبيعة حالة المعاق & 57 \\
\hline 11 & 121 & |توفير مشرف اجتماعي يتفهر حالة المعاق & 58 \\
\hline 9 & 129 & | إتاحة فرص للمعاق للحصول علي مسكن خاص به في المستقبل & 59 \\
\hline 5 & 134 & | للأماكن التي يزيدون مواصلات مجانية تساع المعاق علي الوصول & 60 \\
\hline
\end{tabular}


يتضح من الجدول(8) ان أهم 10احتياجات اجتماعية للمعاقين سمعيا هي علي

$$
\text { التزتيب : }
$$

1- التّريب علي اكتساب المهار ات اللازمة للعمل بمهنة المستقبل.

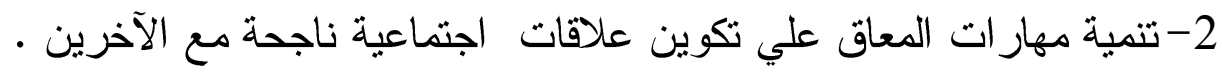

3- إتاحة فرص عمل مناسبة لطبيعة حالة المعاق .

4-تنمية مهار ات التو اصل بين المعاق و الآخرين •

5- توفير وسائل مو اصلات مجانية تساعده علي الوصول للأكاكن التي يريدون

$$
\text { الوصول إليها. }
$$

6- أن لا يشعر المعاق بأن و الديه يخجلون من إعاقته .

7-مشاركة المعاق في أنشطة اجتماعية مع الآخرين. 8-توفير حاسوب و التدريب علي استخدامه.

9- إتاحة فرص للمعاق للحصول علي مسكن خاص باصه في المستقبل.

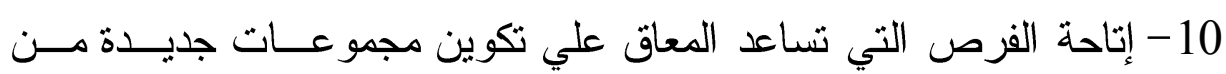

$$
\text { الأصدقاء. }
$$

\section{الحاجات النفسية لذوي الإعاقات الحركية:}

\begin{tabular}{|c|c|c|c|}
\hline التنازليب & الوزن & 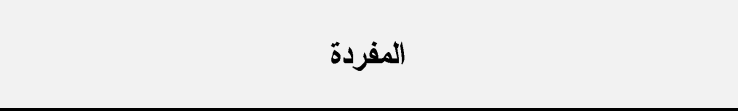 & رقم \\
\hline 15 & 64 & اكتساب الثقة بالنفس لتلافي الثعور بالنقص بسبب الإعاقة & $\mathbf{1}$ \\
\hline 3 & 80 & نحوه إظهار جواتب القوة لدي المعاق لتفادي نظرة الناس السالبة & 2 \\
\hline 10 & 70 & علاج المعاق من الشعور بالاكتئاب & 3 \\
\hline 6 & 75 & من يؤنس وحدة المعاق حتي لا بشعر بالنبذ & 4 \\
\hline 23 & 56 & تكوين علاقات طيبة بين المعاق والآخرين & 5 \\
\hline 16 & 65 & الإرشـاد النفسي للتقليل من إحساس المعاق بالفشل نتيجة لعجزه & 6 \\
\hline 13 & 66 & من يساعد المعاق علي أن يشعر بذاته & 7 \\
\hline
\end{tabular}

جدول (9) : الحاجات النفسية لذوي الإعاقات الحركية والأوزان النسبية لها والترتيب الأبية التنازلي لهذه الحاجات 
مجلة الدراسات التريويتّو الاسانية ـ كلية التربية ـ جامعة دمنهور - المجلا الخامس العدد (1) لسنة 2013

\begin{tabular}{|c|c|c|c|}
\hline 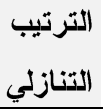 & 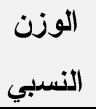 & 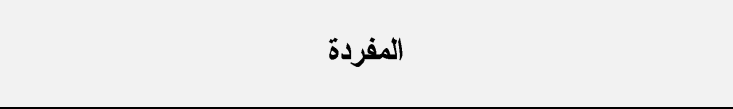 & 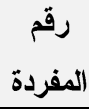 \\
\hline 13 & 66 & من يساعد المعاق علي تقبل ذاته كما هي & 8 \\
\hline 12 & 68 & من يساعد المعاق علي التعامل بفاعلية مع الآخرين & 9 \\
\hline 1 & 85 & أن يفهم الآخرين طبيعة المعاق فهما صحيحا & 10 \\
\hline 2 & 81 & تدريب المعاق علي تحديد أهداف مستقبلية لدياته & 11 \\
\hline 17 & 64 & من يتعاطفون مع ظروف إعاقة الثخص المعاق & 12 \\
\hline 7 & 74 & من يتقبل المعاق كما هوعليه ألان حتي لا يفقد الثقة في نفسه & 13 \\
\hline 18 & 62 & مساعدة المحيطين بالمعاق لكي ينجح في دراسته & 14 \\
\hline 5 & 76 & من يرفع من روحه المعنوية حتي لا يفق الأمل في الحياة & 15 \\
\hline 21 & 58 & إخصائي نفسي يساعده علي حل مشكلاته & 16 \\
\hline 4 & 78 & تو افر رعاية طبية مناسبة للمعاق & 17 \\
\hline 9 & 71 & متابعة دورية لحالة المعاق الصحية & 18 \\
\hline 21 & 58 & ملاعب تصلح لممارسة المعاق للأنثطة الرياضية & 19 \\
\hline 19 & 60 & حدائق يمكن لمعاق التنزه فيها & 20 \\
\hline 20 & 59 & من يساعد المعاق علي تدعيم الجوانب الايجابية في شخصيته & 21 \\
\hline 8 & 73 & فيهائل تسلية وترفيه تساعد المعاق علي شغل أوقات فراغه & 22 \\
\hline 11 & 69 & عدم تعبير الناس عن شفقتهم علي المعاق & 23 \\
\hline
\end{tabular}

يتضح من جدول(9) أن أهم 10 حاجات نفسية لذوي الإعاقات الحركية مرتبة تتازليا هي:

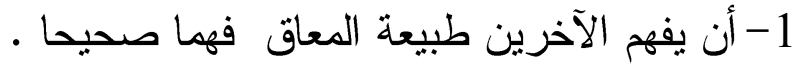
2- تدريب المعاق علي تحديد أهداف مستقبلية لحياته. 3- إظهار جو انب القوة لاي المعاق لتفادي نظرة الناس السالبة نحوه. 4- تو افر رعاية طبية مناسبة للمعاق .

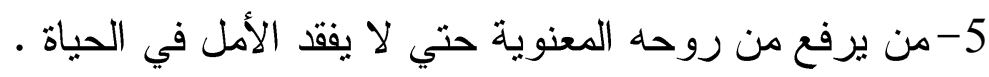

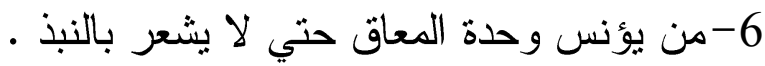

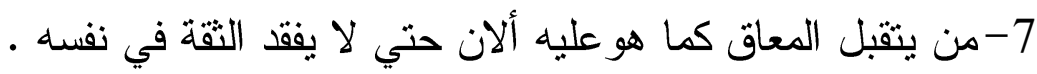

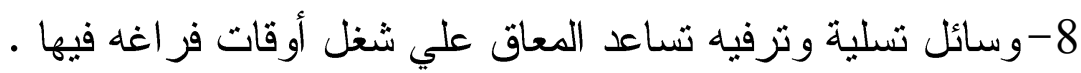


9-متابعة دورية لحالة المعاق الصحية .

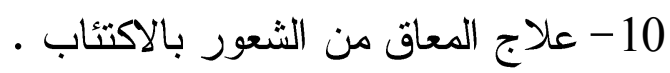

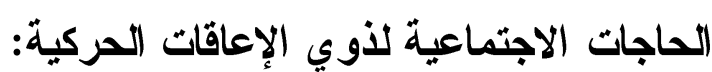

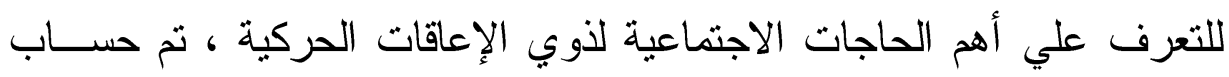

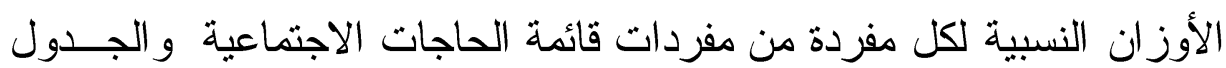

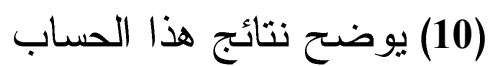
جدول (10) : الحاجات الاجتماعية لذوي الإعاقات الحركية والأوزان النسبية لها والترتيب التتازلي لهذه الحاجات

\begin{tabular}{|c|c|c|c|}
\hline التنازليب & النسبب & المفردة & رقمر \\
\hline 16 & 112 & إن يحترم الآخرين المعاق ولا يسحرون منه & 24 \\
\hline 23 & 103 & أن يجد المعاق من يلعب معه في أوقات فراغه & 25 \\
\hline 15 & 113 & أن يحصل المعاق علي خدمات خاصة لتسهيل تدركاته & 26 \\
\hline 25 & 98 & توفيز رحلات ترفيهية أكثر للمعاقين & 27 \\
\hline 31 & 80 & توفير إخصائي اجتماعي قادر علي فهم ظروف المعاق واحتياجاته & 28 \\
\hline 35 & 65 & يخهم يتقبل الآخرين المعاق للعمل معهم كأحد أعضاء الفريق الأي & 29 \\
\hline 34 & 66 & زيارة الآخرين للمعاق & 30 \\
\hline 3 & 130 & مشاركة المعاق في أنشطة اجتماعية مـع الآخرين & 31 \\
\hline 25 & 98 & أن لا يشعر المعاق بأنه يسبب أي مشكلات بين والايه. & 32 \\
\hline 30 & 85 & أن لا ينبذ الآخرين المعاق بسبب إعاقته & 33 \\
\hline 8 & 123 & أن لا يشعر المعاق بأن والايه يخجلون من إعاقته & 34 \\
\hline 13 & 117 & تنمية مهارات التواصل بين المعاق والآخرين & 35 \\
\hline 5 & 128 & تنمية مهارات المعاق علي اتخاذ القرارات المناسبة & 36 \\
\hline 10 & 121 & تآنمية مهارات المعاق علي تكوين علاقات اجتماعية ناجحة مع & 37 \\
\hline 24 & 99 & إتاحة الفرص التعليمية أمام المعاق للاراسة والتعليم & 38 \\
\hline 13 & 117 & إلتاحة الفرص التي تساعد المعاق علي تكوين مجموعات جديدة من & 39 \\
\hline 27 & 96 & من يساعد المعاق علي ارتداء ملابسه & 40 \\
\hline
\end{tabular}

doi : 10.12816/0001053 
مجلة الدرسات التربياتو الاسانية ـ كلية التربية ـ جامعة دمنهور - المجلد الخامس العدد (1) لسنة 2013

\begin{tabular}{|c|c|c|c|}
\hline التنازليب & 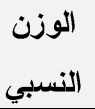 & 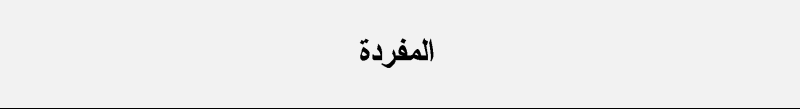 & 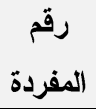 \\
\hline 27 & 96 & من يساعد المعاق علي معرفة كيفية تناول الطعام & 41 \\
\hline 21 & 106 & تعلم كيفية الاستحمام بلون مساعدة من احد & 42 \\
\hline 32 & 79 & تعلم كيفية ممارسة سلوك النظافة الثخصية اليومية & 43 \\
\hline 37 & 59 & تعلم كيفية استخدام الأطراف الصناعية استخاما صديحا & 44 \\
\hline 33 & 73 & تدريب المعاق علي كيفية ارتداء الحذاء بمفردة & 45 \\
\hline 19 & 108 & تدريب المعاق علي ممارسة بعض التمرينات الرياضية المناسبة & 47 \\
\hline 29 & 88 & تدريب المعاق علي صعود وهبوط السلم بمفرده & 48 \\
\hline 22 & 105 & تعلم المعاق كيفية عبور الطريق بمفرده & 49 \\
\hline 18 & 109 & تدريب المعاق علي كيفية حماية نفسه عند الضرورة & 50 \\
\hline 9 & 122 & تدريب المعاق علي تحمل المجهود العضلي & 51 \\
\hline 20 & 107 & أماكن مرتفعة المعاق علي كيفية الحصول علي بعض الأثياء التي توجد في & 52 \\
\hline 6 & 125 & توفير العلاج الطبي المجاني باستمرا & 53 \\
\hline 2 & 138 & تلريب المعاق علي اكتساب المهارات اللازمة للعمل بمهنة المستقبل & 54 \\
\hline 11 & 120 & توفير حاسوب والتّريب علي استخدامه & 55 \\
\hline 1 & 140 & توفير أجهزة تعويضية مناسبة لطبيعة الإعاقة & 56 \\
\hline 4 & 129 & إتاحة فرص عمل مناسبة لطبيعة حالة المعاق & 57 \\
\hline 17 & 111 & توفير مشرف اجتماعي يتفهم حالة المعاق & 58 \\
\hline 12 & 119 & إتاحة فرص للمعاق للحصول علي مسكن خاص به في المستقبل & 59 \\
\hline 7 & 124 & توفير وسائل مواصلات مجانية تساعد المعاق علي الوصول للأماكن & 60 \\
\hline
\end{tabular}

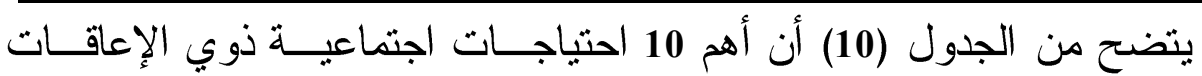

$$
\text { الحركية هي علي التزتيب: لئن من }
$$

1-نوفير أجهزة تعويضية مناسبة لطبيعة الإعاقة.

2-تدريب المعاق علي اكتساب المهارات اللازمة للعمل بمهنة المستقبل. 3-مشاركة المعاق في أنشطة اجتماعية مع الآخرين . 4- إتاحة فرص عمل مناسبة لطبيعة حالة المعاق. 5-تنمية مهار ات المعاق علي اتخاذ القرار ات المناسبة. 


$$
\text { 6-توفير العلاج الطبي المجاني ياستمر ار. }
$$

7-توفير وسائل مواصلات مجانية تساعد المعاق علي الوصول للأماكن التي بالينران

$$
\text { يريدون الوصول إليها. }
$$

8- أن لا يشعر المعاق بأن و الدياه يخجلون من إعبان إعاقته.

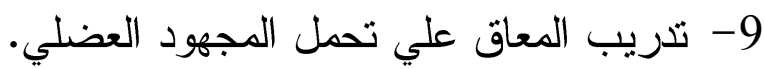

10- تنمية مهار ات المعاق علي تكوين علاقات اجتماعية ناجحة دع الآخرين.

الحاجات النفسية لذوي صعوبات التعلم :

للتعرف علي أهم الحاجات النفسية لذوي صعوبات التعلم ، تم حساب الأوزان

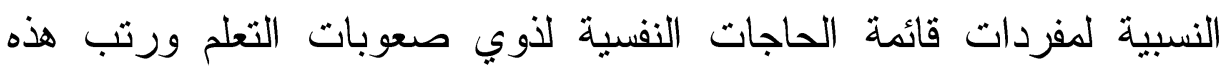
المفردات نرتيبا تنازليا ، و الجدول(11) يبين نتيجة هذا الحساب . 
مجلة الدراسات التريويتّو الاسانية ـ كلية التربية ـ جامعة دمنهور - المجلا الخامس العدد (1) لسنة 2013

جدول (11) : الحاجات النفبية لذوي صعوبات التعلم والأوزان النسبية لها والترتيب

التنازلي لهذه الحاجات

\begin{tabular}{|c|c|c|c|}
\hline التنازليب & النسبني & المفردة & رقم \\
\hline 14 & 69 & اكتساب الثقة بالنفس لتلافي الثعور بالنقص بسبب الإعاقة & 1 \\
\hline 1 & 94 & إظهار جوانب القوة لاي المعاق لتفادي نظرة الناس السالبة نحوه & 2 \\
\hline 2 & 92 & علاج المعاق من الشعور بالاكتئاب & 3 \\
\hline 6 & 80 & من يؤنس وحدة المعاق حتي لا يشعر بالنبذ & 4 \\
\hline 22 & 61 & تكوين علاقات طيبة بين المعاق والآخرين & 5 \\
\hline 13 & 70 & الإرشاد النفسي للتقليل من إحساس المعاق بالفشل نتيجة لعجزه & 6 \\
\hline 11 & 71 & من يساعد المعاق علي أن بشعر بذاته & 7 \\
\hline 11 & 71 & من يساعد المعاق علي تقبل ذاته كما هي & 8 \\
\hline 10 & 78 & من يساعد المعاق علي التعامل بفاعلية مع الآخرين & 9 \\
\hline 3 & 90 & أن يفهم الآخرين طبيعة المعاق فهما صحيحا & 10 \\
\hline 4 & 86 & تلريب المعاق علي تحيد أهداف مستقبلية لحياته & 11 \\
\hline 14 & 69 & من يتعاطفون مع ظروف إعاقة الشخص المعاق & 12 \\
\hline 8 & 76 & من يتقبل المعاق كما هوعليه ألان حتي لا يفقد الثقة في نفسه & 13 \\
\hline 17 & 67 & مساعدة المحيطين بالمعاق لكي ينجح في دراسته & 14 \\
\hline 5 & 81 & من يرفع من روحه المعنوية حتي لا يفقد الأمل في الحياة & 15 \\
\hline 19 & 63 & إحصائي نفسي يساعده علي حل مشكلاته & 16 \\
\hline 16 & 68 & توافر رعاية طبية مناسبة للمعاق & 17 \\
\hline 18 & 67 & متابعة دورية لحالة المعاق الصحية & 18 \\
\hline 19 & 63 & ملاعب تصلح لممارسة المعاق للأنشطة الرياضية & 19 \\
\hline 17 & 65 & حدائق يمكن للمعاق التنزه فيها & 20 \\
\hline 21 & 64 & من يساعد المعاق علي تدعيم الجوانب الايجابية في شخصيته & 21 \\
\hline 7 & 78 & وسائل تسلية وترفيه تساعد المعاق علي شغل أوقات فر اغه فيها & 22 \\
\hline 9 & 74 & عدم تعبير الناس عن شفقتهم علي المعاق & 23 \\
\hline
\end{tabular}

يتضح من جدول (11) أن أهم 10 حاجات نفسية لذوي صعوبات التعلم

هرتبة تنازليا هي: - مري

1 - إظهار جوانب القوة لاي المعاق لتفادي نظرة الناس السالبة نحوه. 


$$
2 \text { - العلاج من الشعور بالاكتئاب. }
$$

3 - أن يفهمه الآخرين فهما صحيحا .

$$
4 \text { - التكريب علي تحديد أهداف مستقبلية لحياته }
$$

5 - من يرفع من روحه المعنوية حتي لا يفقد الأمل في الحياة

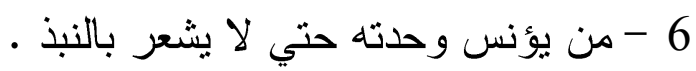

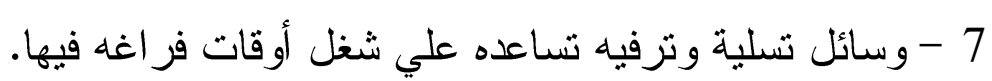

8- من يتقبله كما هو عليه ألان حتي لا يفقد الثقة في نفساه .

9- عدم تعبير الناس عن شفقته علي المعاق ذهنيا .

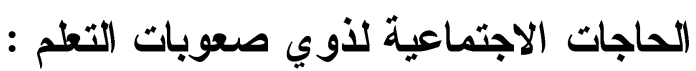

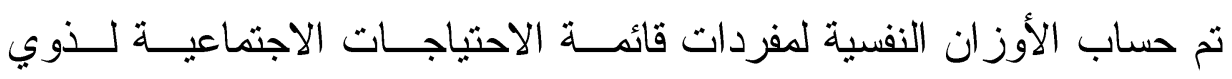
صعوبات التعلم • ثم تم ترتيب الفقرات ترتيبا تنازليا حسب أهميتها و الجدول

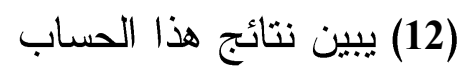


مجلة الدراسات التريويتّو الاسانية ـ كلية التربية ـ جامعة دمنهور - المجلا الخامس العدد (1) لسنة 2013

جدول (12): الحاجات الاجتماعية لذوي صعوبات التعلم والأوزان النسبية لها والترتيب

التنازلي لهذه الحاجات

\begin{tabular}{|c|c|c|c|}
\hline 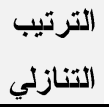 & ال - الوزن & 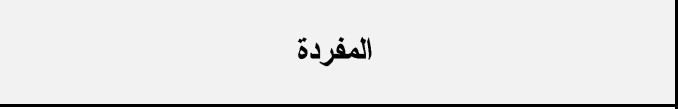 & المفردة \\
\hline 21 & 98 & إن يحترم الآخرين المعاق ولا يسحرون مذه & 24 \\
\hline 8 & 131 & أن يجد المعاق من يلعب معه في أوقات فراغه & 25 \\
\hline 26 & 72 & أن يحصل المعاق علي خلمات خاصة لتسهيل تحركاته & 26 \\
\hline 20 & 109 & توفير رحلات ترفيهية أكثر للمعاقين & 27 \\
\hline 2 & 152 & و توفير إخصائي اجتماعي ق قادر علي فهم ظروف المعاق & 28 \\
\hline 18 & 112 & أن يتقبل الآخرين المعاق للعمل معهم كأحد أعضاء الفريق & 29 \\
\hline 23 & 86 & زيارة الآخرين للمعاق & 30 \\
\hline 7 & 139 & مشاركة المعاق في أنشطة اجتماعية مي الآخرين & 31 \\
\hline 3 & 147 & أن لا بشعر المعاق بأنه يسبب أي مشكلات بين والايه. & 32 \\
\hline 22 & 95 & أن لا ينبذ الآخرين المعاق بسبب إعاقته & 33 \\
\hline 14 & 123 & أن لا يشعر المعاق بأن والديه يخجلون من إعاقته & 34 \\
\hline 11 & 128 & تنمية مهارات التواصل بين المعاق والآخرين & 35 \\
\hline 16 & 117 & تنمية مهارات المعاق علي اتخاذ القرارات المناسبة & 36 \\
\hline 15 & 121 & تناجحة مع الآخرين المعاق علي تكوين علاقات اجتماعية & 37 \\
\hline 23 & 86 & إتاحة الفرص التعليمية أمام المعاق للارسة والتعليم & 38 \\
\hline 16 & 117 & جديدة من الأصدقاء الفرص تساعد المعاق علي تكوين مجموعات & 39 \\
\hline 31 & 38 & من يساعد المعاق علي ارتداء ملابسه & 40 \\
\hline 33 & 37 & من يساعد المعاق علي معرفة كيفية تناول الطعام & 41 \\
\hline 27 & 63 & تعلم كيفية الاستحمام بدون مساعدة من احد & 42 \\
\hline 30 & 53 & تعلم كيفية ممارسة سلوك النظافة الثخصية اليومية & 43 \\
\hline 33 & 37 & تعلم كيفية استخذام الأطراف الصناعية استخذ(ما صديحا & 44 \\
\hline 31 & 48 & تدريب المعاق علي كيفية ارتاءع الحذاء بمفردة & 45 \\
\hline 4 & 143 & الدناسبة المعاق علي ممارسة بعض التمرينات الرياضية & 47 \\
\hline
\end{tabular}

281 


\begin{tabular}{|c|c|c|c|}
\hline التنازتيب & النوزن & 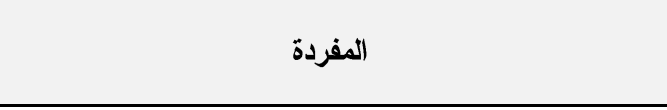 & المفردة \\
\hline 31 & 38 & تدريب المعاق علي صعود وهبوط السلم بمفرده & 48 \\
\hline 25 & 82 & تعلم المعاق كيفية عبور الطريق بمفرده & 49 \\
\hline 6 & 140 & تدريب المعاق علي كيفية حماية نفسه عند الضرورة & 50 \\
\hline 19 & 111 & تلريب المعاق علي تحمل المجهود العضلي & 51 \\
\hline 28 & 60 & التديب المعاق علي كيفية الحصول علي بعض الأثياء & 52 \\
\hline 29 & 57 & توفير العلاج الطبي المجاني ياستمرا & 53 \\
\hline 8 & 131 & تلاريب المعاق علي اكتساب المهارات اللازمة للعمل بمهنة & 54 \\
\hline 1 & 160 & توفير حاسوب والتذريب علي استخدامه & 55 \\
\hline 33 & 37 & توفير أجهزة تعويضية مناسبة لطبيعة الإعاقة & 56 \\
\hline 5 & 141 & إتاحة فرص عمل مناسبة لطبيعة حالة المعاق & 57 \\
\hline 13 & 125 & توفير مشرف اجتماعي يتفهم حالة المعاق & 58 \\
\hline 10 & 129 & إتاحة فرص للمعاق للحصول علي مسكن خاص به في & 59 \\
\hline 11 & 128 & تلوفير وسائل مواصلات مجانية تساعن التي يريدون الوصول الوصول & 60 \\
\hline
\end{tabular}

يتضح من الجدول(12) أن أهم 10 حاجات اجتماعية لذوي صــعوبات الـتعلم

$$
\text { 1-توفير حاسوب و التذريب علي استخداماته . }
$$

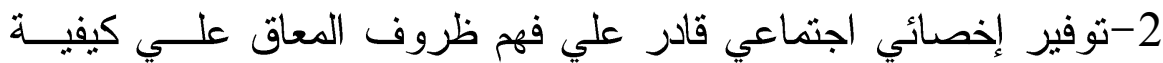

حماية نفسه.

3- أن لا يشعر المعاق بأنه يسبب مشكلات بين و الديه.

4-تدريب المعاق علي ممارسة بعض الأنشطة الرياضية.

5- إناحة فرص عمل مناسبة لطبيعة الإعاقة .

6-تدريب المعاق علي كيفية حماية نفسه عند الضرورة.

7-مشاركة المعاق في أنشطة اجتماعية مع الآخرين. 
8-تذريب المعاق علي المهار ات الازمة للعمل بمهنة المستقبل.

9-أن يجد المعاق من يلعب معه في أوقات فر اغه.

10- إتاحة فرص للمعاق للحصول علي مسكن خاص به في المستقبل.

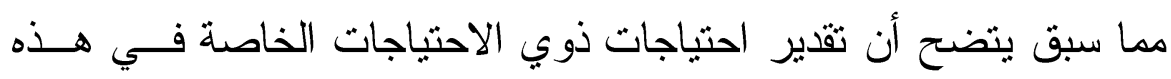
الدراسة هي احتياجات تستحق أن تقدم للمسئولين عن تعليم ورعاية ذوي

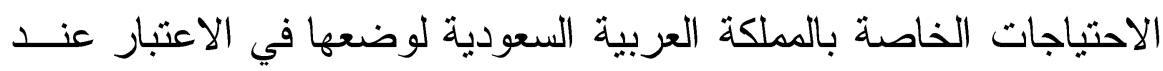
تطوير مؤسسات الرعاية الحكومية و الأهلية ، ولكن هذه النتائج هي نتائج

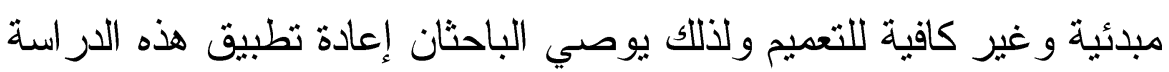

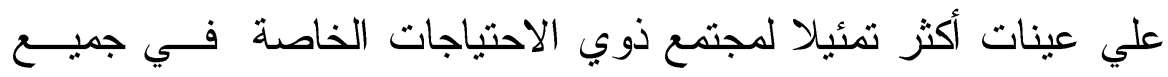

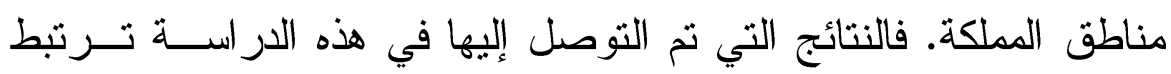
بالعينات المحدودة التي أمكن تطيق قائمة الاحتياجات عليها 
تقدير الاحتياجات النفسية والاجتماعية للمعاقين أد. محمود عبد الحليم منسي د. سحر أحمد حسين سليم 


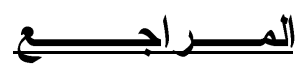

• إولاً : المراجيع العربية

1-أحلام رجب عبد القادر (2003) : تربية المعاقين ذهنياً -دار الفجر للنشر

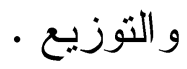

2- إبراهيم ميرغني (1990) : نموتأهيل جمعيات تنمية المجتمع .

3-الثيخ علي محمود (1991): تأهيل العمل الطوعي - معهد در استات درء

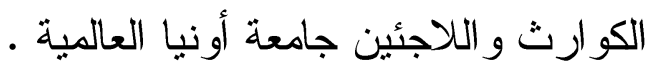

4-المجلس السوداني للجمعيات الطوعية (أسكوفا) (2002) دليل المنظمــات الطوعية.

5-إيراهيم العباس الزهيري (2003) : تربية المعاقين والموهــوبين ونظــــ تعليمهم - دار الفكر العربي - مدينة نصر - القاهرة.

6-محمد سيد فهمي (ب.ت) : السلوك الاجتماعي للمعوقين، دراســة فــي

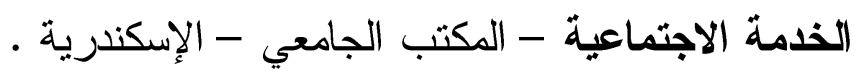
7-عبد الحي محمود حسن صلح (1999): متحدو الإعاقة من منظور الخدمة الإئة الاجتماعية - دار المعرفة الجامعية.

8-قانون رقم 39 لسنة 1985 بالمطابع الأميرية.

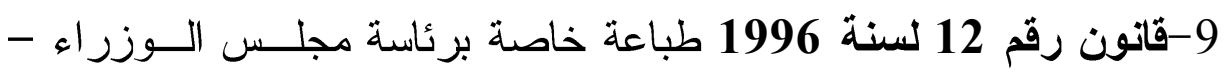
المجلس القومي للطفولة و الأمومة.

10-سعاد حسين (2004): حقوق الطفل المعاق ذهنياً بين الواقع والمأمول

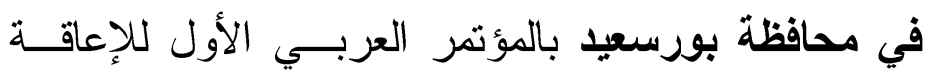

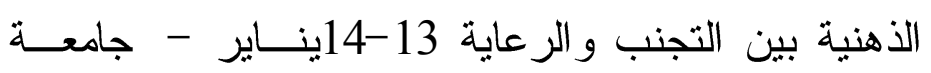
أسيوط.

11-قانون رقم 47 لسنة 1978 و الخاص بالعاملين الدنيين بالدولة الطبعة العشرون المطابع الأميرية. 
12-مدحت محمد أبوالنصر (2004): تأهيل ورعايــة متحــــي الإعاقــة ـ ايتز الك للطباعة و النشر و التوزيع.

13-علي عبده محمود (1994): مرشد جمعيات رعاية وتأهيل المعاقين في مجال التشريعات، اتحاد هيئات رعاية الفئــات الخاصـــة فئة

$$
\text { و المعوقين، ج•م•ع، مارس. }
$$

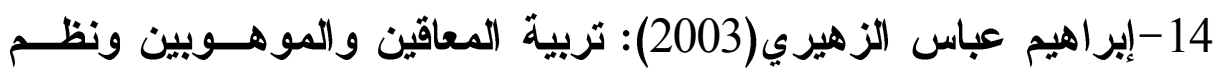

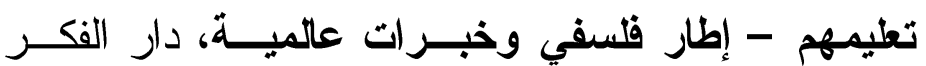

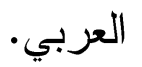

15- أمال صادق (1982): التربية الموسيقية للمعوق، دراسات وبحوث عن

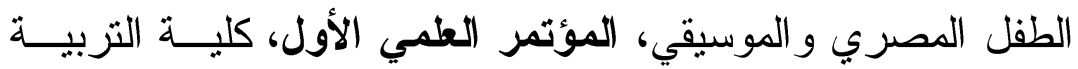

$$
\text { الموسيقية، جامعة حلو ان. }
$$

16-سليمان الخضري (1982) : الفروق الفردية في الـــكاءو، دار الثقافــة للطباعة و النشر . النمري 17-سيد غنيم (1977) : سيكولوجية الثخصية، دار النهضة العربية،

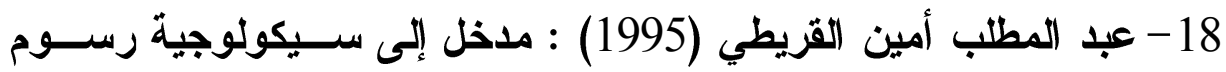
الأطفال، القاهرة، دار المعارف. 19 -عبد المطلب أمين القريطي (1996) : ســيكولوجية ذوي الاحتياجـات الخاصة، القاهرة، دار الفكر العربي. 20-عنايات عبد الفتاح وتراجي عبد الرحمن (1982): دراسة أثر استخدام كل من الإيقاع والموسيقي علي مستوي أداء الجملة الحركية لاي الأطفال، دراسات وبحوث عن الطفل المصري والموسيقي، المؤتمر

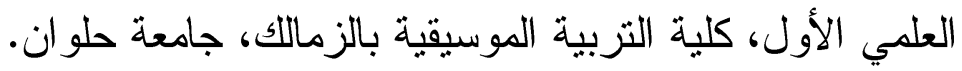


21- عنايات وصفي (1982): أثر الغناء الجماعي في تكوين شخصية الطقل

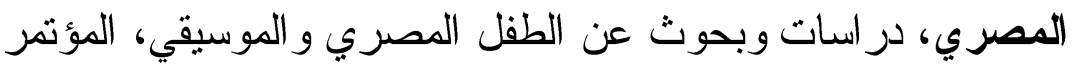

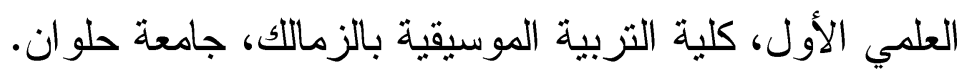

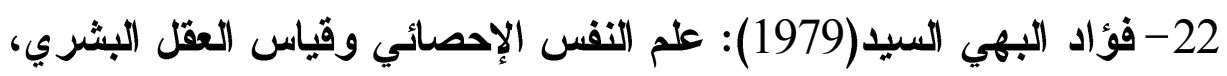
ط3، دار الفكر العربي، القاهرة.

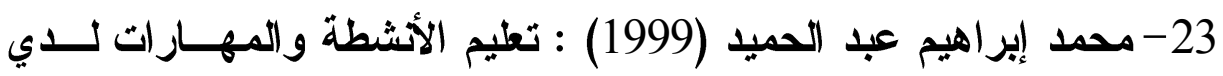
الأطقال المعاقين عقليا، دار الفكر العربي.

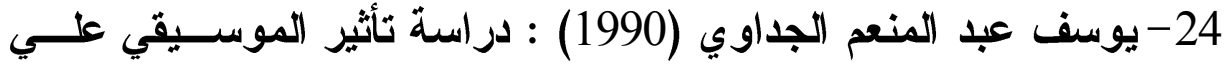

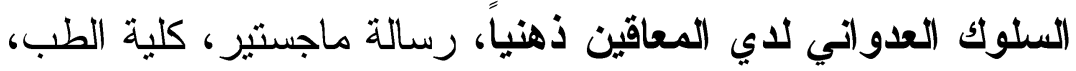
جامعة الأز هر .

25- أصداء المعاقين (2004) ، العقد العربي لذوى الاحتياجــات الخاصـــة 2004 - 2013 العدد و الأربعون، القاهرة . 26- سعاد حسين(2004) ، حقوق الطقل المعاق ذهنيا بين الواقع والمأمول في محافظة بورسعيد، المؤتمر العربي الأول عن الإعاقة الذهنية بين

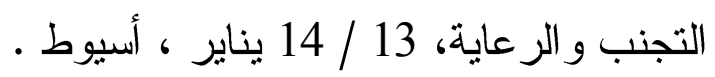

27- ضياء الدين حسن القاضي (2002) ، تاريخ الصحافة، موسوعة تاريخ

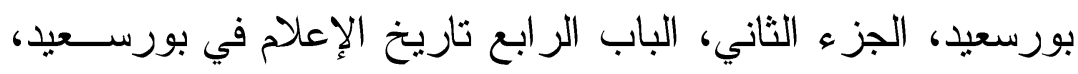
بورسعيد

28- عبد الهادي الجوهري (2002) ، علم الاجتمـــاع السياســي، مفــاهيم وقضايا، المكتبة الجامعية، إسكندرية.

29- مركز النيل للإعلام (2001) ، تطوير التعامـل مــــ ذوى الاحتياجـات

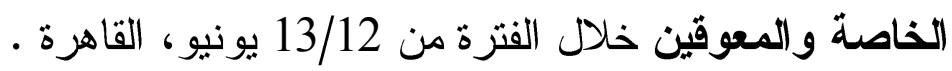
30- اتحاد هيئات رعاية الفئات الخاصة والمعوقين(2001) ، خدمات الجهات المعنية برعاية المعوقين، نشرة دورية، العدد 68، ديسمبر ، القاهرة. 
31- داليا حسن (2001) : أهم ما يتطق بقضايا التطـــوع، رابطــــة المـــراة

$$
\text { العربية، القاهرة }
$$

32- محمد حسين، محمد قريش (2001) : آليات تفعيل دور المنظوع فـــي

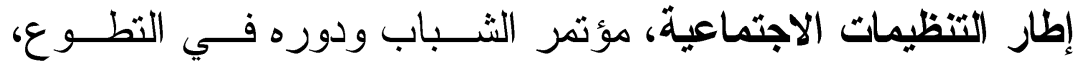

$$
\text { 19/18 ابريل ، القاهرة . الهمبل }
$$

33- احمد كمال احمد (2000) : تنظيم المجتمع، مكتبــة الأنجلو المصـرية،

$$
\text { القاهرة . اهمال }
$$

34- موسى شيتوى (2000) : التطوع والمنظوعون في العـالم العربــي،

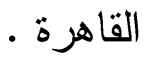

35-سوزان ج .اليس (1999) : تعظيم الموارد التطوعية، الجمعية المصرية

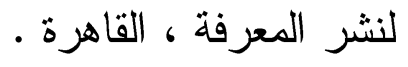

36- محمود مرتضى (1999) : قضايا و إثكاليات العمل التطوعي في مصر،

$$
\text { القاهرة . }
$$

37-سامي عصر (1998) : قضايا التطوع ونظام العمل بالجمعيات، مؤتمر

$$
\text { التنظيمات العربية، القاهرة . }
$$

38- أحمد عزت راجح (1993) : أصول علم الــنفس ـ الإســكندرية، دار

$$
\text { المعارف. }
$$

39- السيد على سيد أحمد وفائقة محمد بلر (1999) : اضطر اب الانتباه لاى الأطفال - أسبابه وتثخيصه وعلاجه ـ القاهرة، النهضة المصرية. 40- الفت محمود نجيب (2000) : مستويات مشاركة الأمهات في البــرامج التدريبية لأطفالهم المعاقين عقليا والتغيرات التي تحلث لاييهم ولدى

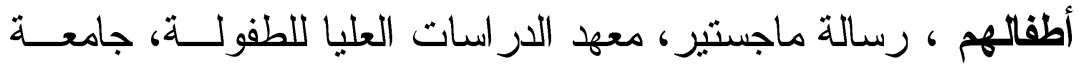


41- جمال الخطيب (1995) : العمل مع أسرة الطفل المعـاق ، منشــورات

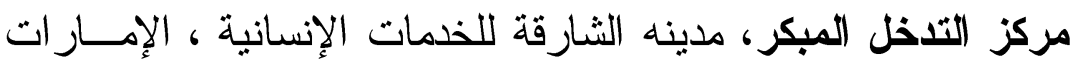
العربية المتحدة.

42- حامد عبد السلام زهران (1998) : التوجيه والإرشــاد النفســي، ط3.

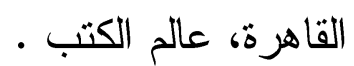
43-زينب محمود شقير (2002) : خدمات ذوى الاحتياجات الخاصة (الدمج

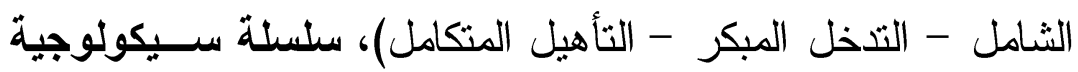

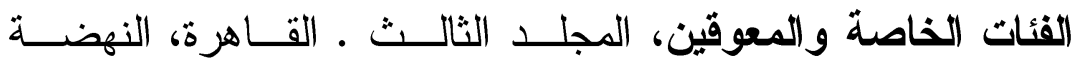

$$
\text { المصرية. }
$$

44-سعدية بهادر (1992) : المرجع فى تربية أطفال ما قبل المدرسة ، ط2

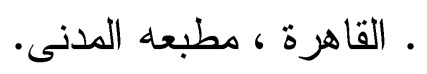

45-سعيد حسنى العزة (2000) : الإرشاد الأســـى نظرياتــهـه وأســاليبه

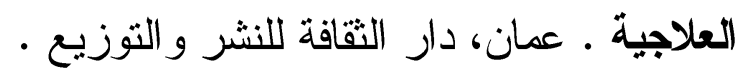

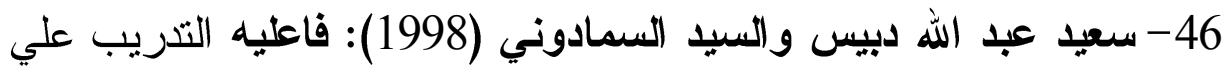

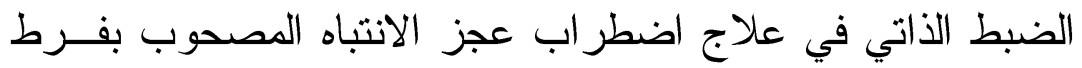

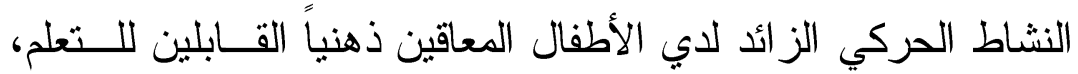

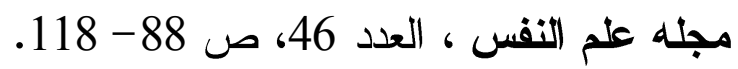
47-سلامة منصور محمد (1997) : دور الإرشاد الأســرى فــى رعايــة

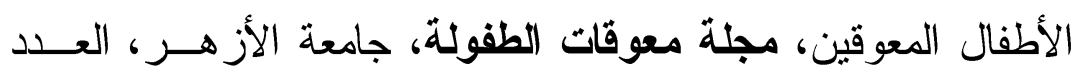

$$
\text { السادس، ص165 -180 -180 }
$$

48-سمية طه جميل (1998) : التخلف العقـــى إســتراتيجيات مواجهــة الضغوط الأسرية ـ القاهرة ، مكتبة النهضة المصرية. 49-سمية طه جميل (2000) : فاعلية برنامج إرشادي في تعديل اتجاهات

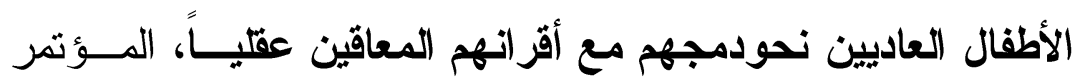


الدولي السابع لمركز الإرشاد النفسي، جامعة عين شمس، ص 611 . 650-

50- شاكر قتديل (1996) : الاستجابات الاففعالية السـلبية لآبــاء الأطفــال

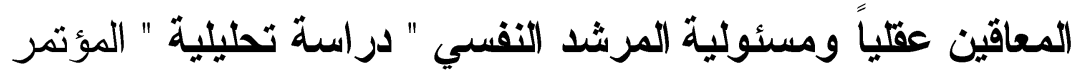

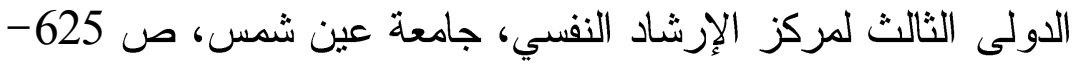

51- ضياء محمد منير الطالب (1987) : دراسة تجريبيــة لأثـــر برنـــــ

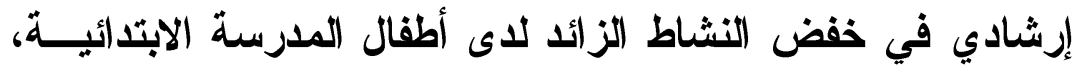
رسالة لكتور اه، كلية التزبية، جامعة عين شمس.

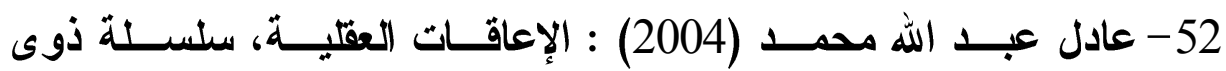

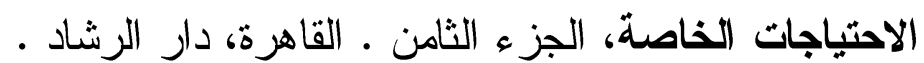
53- عادل عبد الله محمد والسيد محمد فرحان (2001) : أرشاد الوالــدين لتدريب أطفالهما المعاقين عقليا على اســتخدام جــــاول النشـــاط المصور وفاعليته في تحسين مســتوى تفــاعلاتهم ألاجتماعيــهـه .

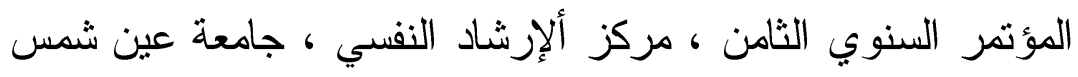

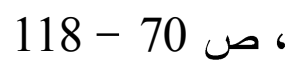

54- عبد الرقيب البحيرى وعفاف محمد عجلان (1997) : مقيــاس انتبــاه

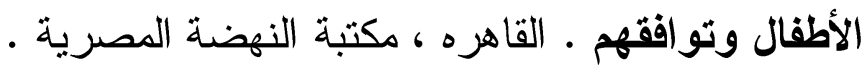
55- عبد الفتاح محمد دويدار (1998): قياس فاعليه إستراتيجيه للإرشــاد

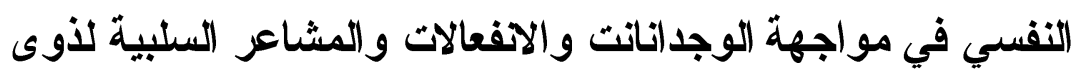

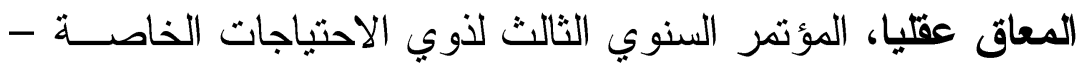
جامعة المنوفية. 
56- علا عبدالباقى ابراهيم قشطه (1995) : مدي فاعليه بعض فنيات تعديل

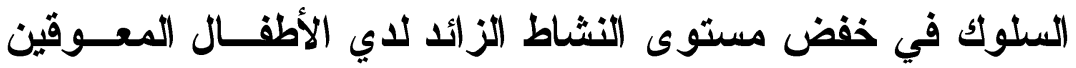
عقليا، رسالة دكتور اه ، كلية التزبية، جامعه عين شمس.

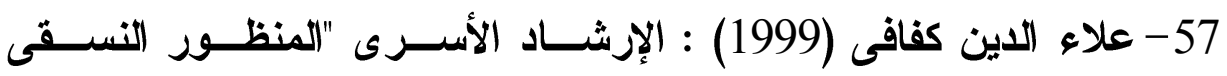
الإتصالى" . القاهرة، دار الفكر العربي. .

58- فاروق صادق (1997) : الحاجة إلى حقيبة إرشادية لأسرة الطفل المعوق دارق

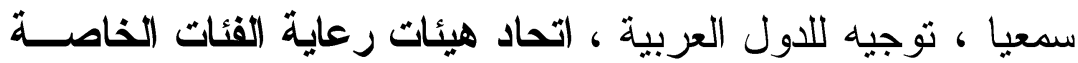

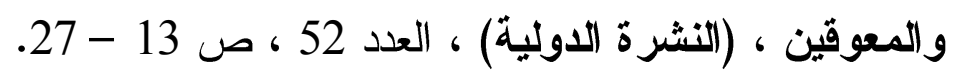

59- كمال إبراهيم مرسى (1999) : مرجع فى علم التخلف العقلي، ط 2 ـ

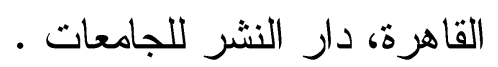

60-كمال سالم سيسالم (2001) : اضطر ابات قصــور الاتبـــاه والحركــة

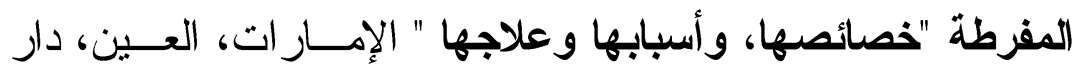

$$
\text { الكتاب الجامعي. }
$$

61-لويس كامل مليكة (1998) : دليل مقياس ستاتفورد - بنيه للـــكاء -

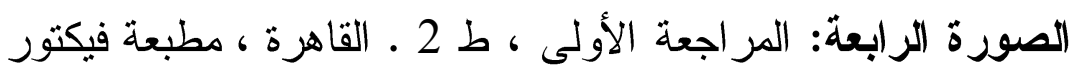

$$
\text { كيرلس }
$$

62-لويس كامل مليكة (1998) :الإعاقة العقلية والاضطر ابات الارتقائيــة .

$$
\text { القاهرة، مطبعه فيكتور كيرلس. }
$$

63 - محمد السيد عبد الرحمن ومنى خليفة على (2003) : تلريب الأطفــال

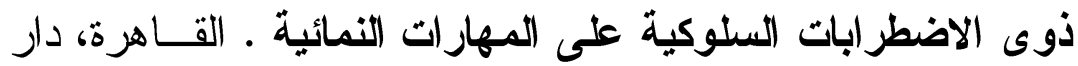

$$
\text { الفكر العربى دوى الاصطر }
$$

64- محمد بيومى خليل (2003) : اتحرافات الثباب في عصر العولمــة . القاهره، دار غريب للنشر و الطباعة. 
65- مواهب ابر اهيم عياد ونعمه مصطفي رقبان وســاميه ابــر اهيم لطفـي

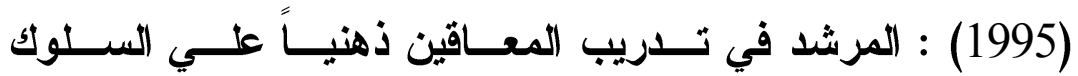

الاستقلالي في المهارات المنزلية، الاسكندريه منشأه المعارف.

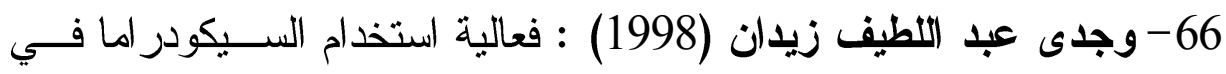

العلاج الأسرى لتحسين التواصل لدى الأبوين المسنين، مجلة كلية

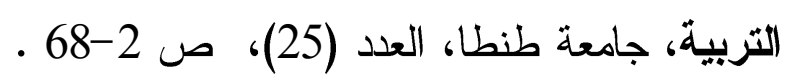

67- المجلس القومي للطفولة والأمومة (92-1997) : الخطة القومية للحد

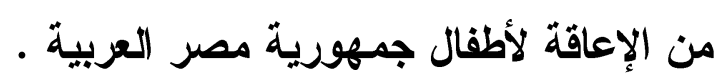

68- منظمة الصحة العالمية (1999) : المراجعة العاشرة للتصنيف الــدولي الـي للأمر اض ICD-10 تصنيف الاضطر ابات النفسـية والســـوكية،

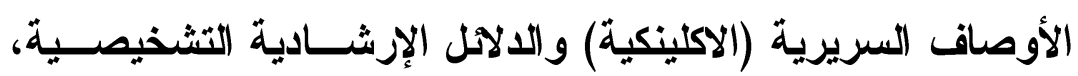

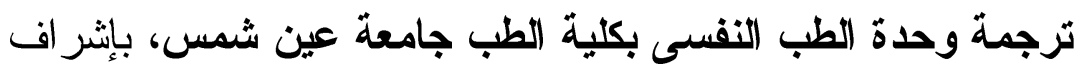

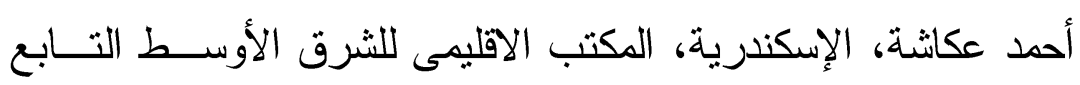
لمنظمة الصحة العالمية .

69-وزارة التربية والتعليم (2003) : إحصاءات وملقات التربية الخاصــة، إدارة التربية الخاصة القاهرة .

\section{• ثانبيا المر اجي الأجنبية :}

70-Aman, L. (2001): Family System Multi- Group Therapy for ADHD Children and their Families, Dissertation Abstracts International, -B p.5548.

71-American Psychiatric Association (1994): Diagnostic and Statistical Manual of Mental Disorders, 4th ED., DSM-IV, Washington, DC., American psychiatric press..

72-Barkley, R. (1995): Taking Change of ADHD: The Complete Authoritative Guide for Parents, New York, Guilford press 73-Barkley, R., Godzinsky, G., \& Dupaul, G. (1992): Frontal Lope Function in Attention Deficit Disorder With and Without Hyperactivity: A Review and Research Report, Journal of Abnormal Child Psychology. Vol. 20, No. 2, p. 163- 184. 
74-Barkley, R., Guevremont D., Anaslopoulos A., \& Fleteher K. (1992): A Comparison of Three Family Therapy Programs for Treating Family Conflicts in Adolescents with Attention Deficit Hyperactivity Disorder. Vol. 60, No.3, p. 450- 562

75-Brito, G. Pinto, R., \& lins, M., (1995): A Behavioral Assessment Scale of Attention Deficit Disorder in Brazilian Children based on DSM - III - R Criteria, Journal of Abnormal child psychology, No., 23, p 509-521.

76-Brooks, R \& Goldslein, S.,(2003): Nurturing Resilience in our Children, Conlemporary Books.

77-Corell, O., \& Huthchison, J. (1987): A comparison of recommended treatment approaches: Attention Deficit Disorder Versus Aggressive Under Socialization Conduct Disorders, Dissertation Abstracts International-B Vol. 47, No. 11, p. 4645

78-Corey G. (1996): Theory and Practice of Counseling and Psychotherapy an International Thomsen Publishing Company, Washington.

79-Corkum, P., Rimer, P., \& Schachar, R. (1999): Parental knowledge of Attention Deficit Hyperactivity Disorder and Opinions of Treatment Options: Impaction Enrolment and Adherence to a 12 Month Treatment Trial, Canadian Journal of Psychiatry, Vol.44, No. 10, p.1043- 1049.

80-Corrin, E., (2004): Child Group Training Versus Parent and Child Group Training for Young Children with ADHD, Dissertation Abstracts International-B Vol. 64, No. 7, p. 3516

81-Corsini, R. (1996): Encyclopedia of Psychology; Second Edition. Singapore, New York.

82-Cunninqham C., Clark M., Louise, R., \& Durrant. (1989): The Effect of Coping Modeling Problem Solving and Contingency Management Procedures on the Positive and Negative Interaction of Hearing Disability and Attention Deficit Disorder Children with an Autistic Peer, Child and Family Behavior Therapy Vol. 11, No. 3, p. 89-106.

83-Danforth, J. (1999): The Outcome of parent Training Using the Behavior Management Flow Chart with a Mother and her boys with Oppositional Defiant Disorder and Attention Deficit Hyperactivity Disorder, Child and Family Behavior Therapy, Vol. 21, No. 4, p. 59-80. 
84-Das. J. (1996): Mental Retardation and Assessment of Cognitive Process, Manual of Diagnosis and Professional Practice in Mental Retardation. Washington, DC.

85-Daupaul, G., Schaughency, E., Weyandt, L., Trippi, G, Kiesner, J., Ota, K., \& Stanish, H. (2001): Self Report of ADHD Symptoms in University Students: Cross - Gender and Cross -National Prevalence, Journal of learning disabilities, Vol. 34, No. 4, p. 370- 380.

86-Dupaul, G., Anastopoulos, A., power, T., Murphy, K., \& Barkley, R. (1994): The ADHD Rating scale -IV Unpublished Manuscript, Lehigh University, Bethlehem, PA.

87-Edwards, J. (2002): Evidence - Based Treatment for Child ADHD: "Real -world " Practice Implications, Journal of Mental Health Counseling, Vol.24, No.2, p. 126 - 140.

88-Ellison, M (2004) : The Effect of Non-Verbal Redirection on Out of seat Behavior in a Subject Diagnosed as ADHD and MR , Dissertation Abstracts International-B Vol. 42, No. 3, p. 732

89-Fee, V., (1993): The Differential Validity of Hyperactivity/ Attention Deficits and Conduct Problems Among Mentally Retarded Children, Journal of Abnormal Child Psychology, Vol. 21, No. 1 p. 1-11.

90-Flynn, R., \& Hopson, B. (1981): Inhibitory Training: An Alternative Approach to Development of Controls in Hyperactive Children. In Reid \& Hresko (EDS). A Cognitive Approach to Leaming Disabilities New York: Mac Graw Hill, Inc.

91-Forehand, R., \& McMahon, R. (1981): Helping The Noncompliant Child: A Clinician's Guide to Parent Training, New York; Guilford press.

92-Frank, J., George, H., Laurie, E., \& Catherine, L. (1996): Manual of Diagnosis And Professional Practice in Mental Retardation, American Psychological Association, Washington, DC.

93-Frankel, F., (1997) :Parent Assisted Transfer of Children's Social Skills Training: Effects on Children with and without Attention Deficit Hyperactivity Disorder, Journal of American Academic Child Adolescence Psychiatry, Vol. 36, No. 8, p. 1056- 1564 
94-Gladding,. S. (1988): Counseling a Comprehensive Profession, Columbus, Toronto, London

95-Goth, A (1993): Siblings of Mentally Related Children Midwife, Health Visitor and Community Nurse, Vol. 26, No. 4. p 81

96-Graham, P. (1998): Cognitive -Behavior Theory for Children and Families, Cambridge University press.

97-Grisanzio, W. (2001): Evaluation of Effectiveness of An Attention Enhancement Program for Children Diagnosed with ADHD Administered in the School setting, Dissertation Abstracts International-B, p. 5043.

98-Harvey, E., (2000): Parenting Similarity and Children with Attention Deficit Hyperactivity Disorder, Child and Family Behavior Theory Vol. 22, No. 3, p. 39-54

99-Johannes R., \& Marc J. (1996): Manual of Diagnosis and Professional Practice in Mental Retardation, American Psychological Association Washington, DC.

100- Johnson, C., \& Handen, B. (1994): Efficiency of Mental Penidate Intervention on Classroom Behavior in Children with ADHD and Mental Retardation, Behavior Modification, Vol. 59, No. 4, p. 470-488.

101- Kaufman,K (2004): Parental Satisfaction with Evaluation for Attention Deficit Hyperactivity Disorder, Dissertation Abstracts International-B Vol. 64, No. 7, p. 3528

102- Malacrida, C. (2001): Motherhood, Resistance and Attention Deficit Disorder: Strategies and Limits, Canadian Review of Sociology \& Anthropology, May Vol. 38, No. 2, p. 141166.

103- Martin, T (2001): ADHD, Divorce and Parental Disagreement about the diagnosis and treatment, pediatrics, Vol. 107, No. 4, p. 867- 873 .

104- McCain A., \& Kelley M., (1993): Managing The Classroom Behavior of an ADHD Preschooler: The Efficacy of School me note Intervention Child and Family Behavior Therapy, Vol. 15, No. 3, p. 33-44.

105- McKay, M., Gonzales, J., Quintana, E., Kim, L., \& Abdul, J. (1999): Multiple Family Group: An alternative for reducing disruptive behavioral difficulties of urban children, Social work practice, Vol. 9, No. 5, p. 593- 608.

106- Merrell, K., \& Boelter, E. (2001): An Investigation of Relationships Between Social Behavior and ADHD in 
Children and Youth, Journal of Emotional \& Behavior Disorders, Vol. 9, No. 4, p. 260-272.

107- Noble, F (1991): Counseling Couples and Families, Introduction to Counseling, Ally and Becon.

108- Patterson, G. (1976): Living With Children: New methods for parents and teachers. Champaign, II; Research press.

109- Pfiffner, L., \& McBurnett, K. (1997): Social Skills Training with Parent Generalization: Treatment Effects for Children with Attention Deficit Disorder, Journal of Consulting Clinical Psychology, Vol. 65, No. 5, pp 749-757.

110- Phyllis, A (1998): Intervention For ADHD Treatment In Developmental Context, New York, The Guilford Press.

111- Reid, W. (1985): Family Problem Solving, Columbia University Press, New York

112- Rosenberg, A. (1999): Pagination "Parent Training For Families of Children Diagnosed With Attention Deficit Hyperactivity Disorders, Dissertation Abstracts International - B Vol. 59, No. 9, pp 5068.

113- Suarez L., \& Baker, B. (1999): Child Extemalizing Behavior and Parent's Stress: The Role of Social Supports, Vol. 46, No. 4, p. 372-382

114- Swanson, J. (1992): School Based Assessment and Interventions for ADD Students. Irvine, CA : K.C.

115- Vaught, P., (1990): Parental Perception of Children Clinically Diagnosed as Attention Disorder, Attention Deficit Hyperactivity Disorder or Conduct Disorder: The implication for Family Theory, Dissertation Abstracts Intemational - B 51/05 Nov. p.2638.

116- Walker C., \& Element P., (1992): Treating Inattentive, Impulsive Hyperactive Children with Self-Modeling and Stress Inoculation Training, Child and Family Behavior Therapy, Vol. 14, No.2, p. 75-85

117- Woltersdorf, $M$ (1992): Video Taps Self Modeling in Treatment of Attention Deficit Hyperactivity Disorder, Child and Behavior theory, Vol. 14, No. 2 p. 134-147.

118- Zentall, S., \& Meyer, M., (1987): Self - Regulation of Stimulation for ADD -H Children During Reading and Vigilance Task Performance, Journal of Abnormal child psychology, Vol., 15, p 519-536. 
مجلة الدراسات التريويتو الاسانية ـ كلية التربية - جامعة دمنهور - المجلد الخامس العدد (1) لسنة 2013 


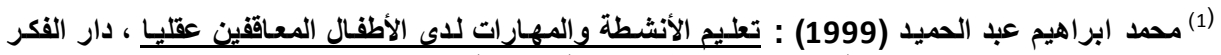

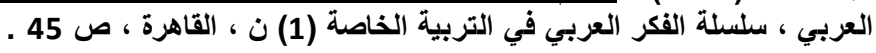

(2) كمال (براهيم مرسي ( 1996 ) : مرجع في علم التخلف العقلي ، دار القلم ، الكويت .

${ }^{(3)}$ Combs ، M \& S. Slaby (1977): Social Skills Training with Children in Advances in Clinical Child Psychology. Vol. Plenum. Press New York.

(4) محمد السيد عبد الـرحمن ( 1988 ) : دراسـات في الصحة النفسية ، المهارات الاجتماعية ، الاستقلال النفسى ، الهوية ، مح 2 ، دار القباء للطباعة و النشر القاهرة ، ص النس 80.

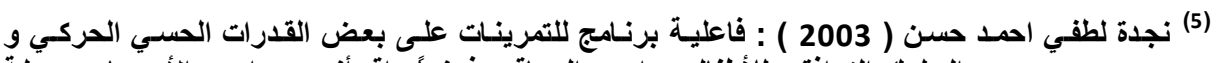

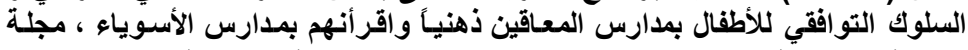

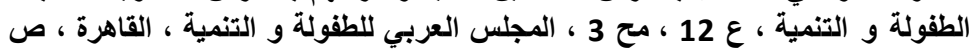

(6) نادر فهمي الزيود ( 1995 ) : تعليم الأطفال المتخلفين عقليًا، ط3 ، دار الفكر للطباعة و النشر و التوزيع

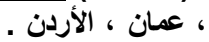

(1) عبد المطلب امسين القريطي ( 1996 ) : سـيكولوجية ذوى الاحتياجـات الخاصـة و تـربيتهـ ، دار الفكر (2) محمد سيد فهي ( 1998 ) : السلوك الاجتماعى للمعاقين ، دار المعرفة الاجتماعية ، الإسكندرية . (3) تهاني عبد السلام محمد ( 1993 ) : أسس الترويح و التربية الترويحية ، دار المعارف الإسكندرية ، ص .235

(4) حلمي ابراهيم ، ليلى فرحات ( 1998 ) : التربية الرياضية و الترويح للمعوقين ، دار الفكر العربي. ص 